\title{
A study of higher education students' self- perceived digital competences for learning and everyday life online participation.
}

MARTZOUKOU, K., FULTON, C., KOSTAGIOLAS, P. and LAVRANOS, C.

This author accepted manuscript is deposited under a Creative Commons Attribution Non-commercial 4.0 International (CC BY-NC) licence. This means that anyone may distribute, adapt, and build upon the work for non-commercial purposes, subject to full attribution. If you wish to use this manuscript for commercial purposes, please contact permissions@emerald.com 


\title{
A study of Higher Education students' self-perceived digital competences for learning and everyday life online participation
}

\author{
Konstantina Martzoukou, Crystal Fulton, Petros Kostagiolas, Charilaos Lavranos
}

\begin{abstract}
Purpose: An increasing amount of research and debate has emerged over the last few years, emphasising the need for developing digitally competent, literate, able, skilled, capable people within a constantly changing technological and online environment. Existing definitions and perspectives in this area go beyond the use of technological tools or media for the creation of a digital literacy mindset, which develops throughout one's life. However, Higher Education strategies have not yet caught up with this agenda.
\end{abstract}

Design/methodology/approach: A student survey with Library and Information Science students from three higher education institutions in Scotland, Ireland and Greece was conducted as a basis of empirical data to support the theoretical propositions of the study. The survey centered on the technical and higher-level digital competences of students, and drawing from students' self-perceived digital competences for learning and for the everyday life digital context, addressing e-leisure, e-learning, e-democracy, e-government, and e-health activities. The survey critically enabled students to assess digital competences from their perspectives as digital participants.

Findings: Students' self-assessment of digital competences were lacking in a number of areas, which involved the development of information literacy, digital creation, digital research and digital identity management. In addition, students' digital competences were found to be linked to previous experiences within the everyday life digital environment. The higher the selfperceived digital competence levels of students were on the basis of dealing with everyday life digital tasks, the more likely they were to also develop high self-perceived digital competence in other digital areas related to their education.

Originality/value: Higher education has not fully embraced digital competences as a core, fundamental literacy which addresses both technology mastery and a digital citizenship mindset. As emerging models begin to challenge traditional teaching and learning paradigms, with global connectivity and personalised approaches, existing digital divides may be further accelerated. This requires revisiting digital competences with emphasis on the diversity of the contexts where it develops and of the learners involved, in the overall continuum of learning for life. 
Keywords: digital competences, digital literacy, information literacy, everyday life, higher education, life-long-learning, student transitions, empirical research.

Article Classification: Research paper

\section{Introduction}

An increasing amount of research has emerged over the last few years that emphasises the need for developing digitally competent, literate, able, skilled, capable people within a constantly changing technological and online environment (Fulton and McGuinness, 2016). In particular, the Covid-19 pandemic has sharpened social focus on the need for digital skills (Iansiti and Richards, 2020). However, the definition, terminology, ownership and responsibilities created within this domain are contested, with a plethora of debates and different opinions in respect to what individuals should master and accomplish in order to become sufficiently 'digital'. In addition, different needs and demands are created within the fast growing technological and interconnected environment that the world of the Internet has to offer in diverse areas of everyday life, education, work, civic responsibility, and health. A proliferation of definitions around digital competence and digital literacy has emerged with variant terms used and different nomenclature. Within the domain of Higher Education, which forms the focus of this paper, useful reviews of the terms can be found in the work of Ilomäki et al. (2011) and Spante et al. (2018). Blurred terminology and contested frameworks are effectively summarised by the UK Department for Business Innovation \& Skills and Department for Culture Media \& Sport (2016), defining digital literacy as "encompassing multiple types of skill-sets such as basic, operational, cognitive, social and attitudinal" but with "lack of clarity around the types of digital competencies necessary for certain tasks to be performed by specific user groups" (p.24).

However, moving away from the issue of terminology, which is beyond the focus of this work, there has been relative agreement in different domains that critically discuss digital literacy and digital competence, on the basis that these involve not only technology mastery, i.e. the abilities, competencies, capabilities, and skills required for using digital technology, media and tools, but also a digital mindset, which consists of attitudes and behaviours necessary to develop as a critical, reflective and life-long 21st century learner. In this vain, Bawden $(2001 ; 2008)$ dwells into the notion of skill-based literacies, information literacy and digital literacy, relating them to broader considerations such as sociocultural views of literacies, organized practices and human behaviour within the information society. Central to this should be "understanding, meaning and context", addressing questions of who needs them, why they are important and within what contexts (Bawden, 2001). This two-fold interpretation focusing on technology mastery but also on digital mindsets within context is conceptualized by Gazi (2016) as "a 
socially constructed set of practices and the norms of behaviours" which "facilitates individual development and protects social values in digital society" (p.139), linking back to the original idea of Paul Gilster's approach to being digitally literate, which is about "mastering ideas not keystrokes" (Gilster, 1997; p.15).

The European Digital Competence Framework for Citizens (Carretero et al., 2017) has captured this two-fold interpretation with an added emphasis on diverse digital society contexts, focusing on the necessity to improve citizens' digital competence for work and employability, learning, leisure, consumption and participation. Digital competence is grouped into five areas which denote both technical as well as behavioural/attitudinal aspects, involving critical thinking, reflection and life-long learning, information and data literacy, communication and collaboration, digital content creation, innovation, safety and problem solving.

The International Federation of Library Associations and Institutions (IFLA), has similarly used the term 'digital literacy' to describe "the ability to harness the potential of digital tools", as a concept which incorporates not only technical elements, i.e. using technology... but also understanding of how to use the Internet to its "fullest effect - efficiently, effectively and ethically - to meet information needs in personal, civic and professional lives" and lead to "personal fulfillment, and professional and entrepreneurship opportunities". This also involves using the Internet creatively and safely, understanding risks associated with privacy as well as the legal and ethical impact of global citizenship, which requires to be guided by standards of online behavior (IFLA, 2017).

This direction is also evident within the Higher Education domain, in debates, placing focus on addressing capabilities required by all university students to thrive as effective and responsible participants in a digital society (UK Higher Education Academy, 2017; Bawden and Robinson, 2002; Ng 2012; Fulton et al., 2020;). For example, work by JISC (2012) on the 'Developing Digital Literacies programme' (DDL) supported students' development of digital literacies as "capabilities which fit an individual for living, learning and working in a digital society", highlighting a number of areas, including the use of digital tools as well as digital professionalism, communicating ideas effectively, collaborating in virtual networks and using digital technologies to support reflection (JISC, 2014). In addition, McGuinness and Fulton (2019) explored student development of critical digital literacy skills through a blended learning approach in the classroom that utilized reusable learning objects.

A recent study by Kara (2018), echoes that notion further, offering an overview of several different facets of "digital citizenship" skills required of university students, consisting not only of expected or normative behaviour around the use of technology but also of the social behaviour and values required in a digital society, as an electronic counterpart of a the real 
society, where people engage in diverse activities, involving working, socializing, buying, trading and learning (Hollandsworth et al., 2011). In that way, a number of important areas for understanding the tenets of digital citizenship can be identified, including: etiquette, communication, education, access, commerce, responsibility, rights, safety and security (Ribble and Bailey, 2004).

Despite the above emphasis, universities have not yet developed a systematic approach to exploring and mapping the digital competences of students, embracing both technology-based and 'digital citizenship' areas as a priority agenda. There is a proliferation of practical skillsbased short courses and online resources developed by universities to help students achieve a baseline of skills for the academic environment and the working place on the basis of "industry/workplace relevant digital skills" "academic skills" and "digital design/content creation" skills (Morgan, 2019; p.12), but there are usually no systematic attempts made to understand students' existing digital competences within the continuum of students' lives, looking at how already developed digital skills, attitudes, beliefs and behaviour influence subsequent interactions with the digital learning environment.

\section{Research Argument and Rationale}

Recent movement in HE towards institutional information and digital literacy strategies offers a positive step towards devising cross-departmental/subject policies in enhancing students' and staff digital literacy (The Open University, 2016) and recognising the importance of "core digital skills for successful study, employability and lifelong learning" (Ulster University, 2017; p.3). For example, at the heart of university initiatives, lie conversations about the development of students' digital skills from the perspective of 'graduate employability' agendas, which aim to prepare students with digital skills required by employers (Morgan 2019). These are unquestionably positive developments for the Higher Education sector.

However, few universities involve an exploration or mapping of students' digital competences and these usually focus on technology use, e.g. which technologies students use and which ones they are reluctant to integrate into their academic life (University of Exeter; JISC, 2015a). Many universities design resources to help students develop their digital skills, but these are usually aimed at baseline levels and students existing digital competences are not considered, approaching students as a digital homogenous group (see for example, "My Digital Literacy" at the University of Bolton, the "Pre-entry Information and Digital Literacy Tutorials" by the University of Sheffield, the "Digital Capabilities for Students" online module by Oxford Brookes University, and the "Transition Skills Programme" by Queen's University Belfast). This may also mean that students with advanced digital competences may have fewer opportunities to further accelerate these skills. 
University students are diverse on the basis of different demographics such as age (e.g. mature students), geographical location (e.g. international students), previous education and work (e.g. widening access students), which may create demands for variant levels of support for digital competences as well as accelerate digital inequalities. This is evidenced, in broader social science research which highlights how diverse socio-demographic characteristics (age, income, level of education, disabilities), creates two levels of citizens: those who are digitally enabled and those who are digitally divided, both on levels of digital connectivity (e.g. access to the Internet) and digital skills (Good Things Foundation, 2018; Ofcom, 2020; Moore et al., 2018). Existing priorities and directions mapped in government national initiatives (e.g. on the basis of reducing the existing digital divide) illustrate this further. For instance, the UK Digital Strategy 2017, highlights that not everyone has digital skills required to participate fully in the digital economy and society (UK Department for Digital, Culture, Media \& Sport, 2017). It is estimated that "Currently, 10.5 million people in the UK lack basic digital skills and many either can't or don't use digital government services independently" (Crown Commercial Service, 2016). A number of strategies have been developed under this agenda, such as the 'Internet Safety Strategy' (UK Department for Digital, Culture, Media \& Sport and The Rt Hon Karen Bradley MP, 2018), to tackle the everyday life digital competences around the ethical, critical and responsible use of information for all citizens.

At the same time, predominant within Higher Education is still the differentiation between the so-called digital natives and digital immigrants (Prensky, 2001) and the concept of young people 'growing up with technology' despite this theory having been challenged multiple times, since it was first published (Bennett et al., 2008; Margaryan et al., 2011; White and Le Cornu, 2011). Digital Natives are often seen as the forerunners of the information society and the digital economy, as those who have already developed digital competencies as part of their everyday life experiences, using digital technologies and the Internet. However, as Bennett et al. (2008) put it (and highlighted by White and Le Cornu, 2011):

“...there also appears to be a significant proportion of young people who do not have the levels of access or technology skills predicted by proponents of the digital native idea.... Such generalisations about a whole generation of young people thereby focus attention on technically adept students. With this comes the danger that those less interested and less able will be neglected, and that the potential impact of socioeconomic and cultural factors will be overlooked.” (Bennett et al., 2008; p.7).

Therefore, not all students arrive at university with the same digital competences and it is important to consider 'widening participation' and 'digital inclusion' perspectives, which recognise that learners have diverse digital experiences on the basis of complex background 
characteristics. Elder et al., (2003) describe this as a 'life-course' perceptive which denotes a lifelong learning process, considering learners' "individual educational pathways within their institutional and social embeddedness (e.g., within not only formal educational institutions but also nonformal/informal contexts such as the family, peer groups, and other social networks)" (Blossfeld and von Maurice, 2019; p.17). Approaching the development of digital competences in such a way means that a fundamental question for educators is, therefore, how to understand and relate to students' different levels of digital experiences and competences within diverse online contexts but also how to empower students to develop a proactive engagement with developing their own digital competencies for life.

\section{Students' Digital Challenges}

Research has found that the online world brings new challenges for young people, such as judging the credibility of information (McGrew et al., 2018, pp.4-5; National Literacy Trust, 2018; Picton and Teravainen, 2017) via social media, a complex advertising personalising environment and misplaced expectations that search engines such as Google provide "some kind of authenticating role, in that if a website is listed by the search engine then it can be trusted" (Ofcom, 2017; p.5) which remains as an unchanged phenomenon (Ofcom, 2020). Earlier studies have discussed the characteristics of the so-called Google generation which include less sophisticated and surface information seeking strategies, shallow online reading (e.g. Liu, 2006) and lack of critical evaluation of the information that is accepted as 'good enough' information (Rowlands et al., 2008). These findings suggest that young people may require support to develop into "active and informed in their citizenry online" to be in a position "to intervene positively in negative situations online ... consume online information critically ... engage positively in online social and political discussions, and to understand the dynamics of social media" (p.19).

In addition, existing research on university students' 'digital citizenship' engagement, has found that not all students may engage effectively in digital citizenship practices, such as edemocracy and e-government and may favour informal online activities centered on communication, leisure and entrainment (Martzoukou and Sayyad, 2017). For example, Kara (2018), who explored the factors affecting university students' thoughts and practices regarding 'digital citizenship', found that although nearly half of the students were engaged with social and cultural activities, such as signing online petitions related to social, cultural, political, or economic issues, they did not prefer being involved with political activism on the Internet, expressing a need for safety, as other people did not necessarily follow moral and ethical values when interacting online. In a study of e-democracy of university students studying Law (Balog and Siber, 2014) found that the majority of students did not actively 
participate in e-democracy activities or engaged with e-government content, but instead favoured informal online activities centered on communication, leisure and entrainment calling for more curriculum focus on e-democracy issues. Torney-Purta et al. (2015) note how the "participatory and involvement skills" of civic engagement address "the ability to identify the most promising action in a group situation or in solving a social or civic problem. They include effective ways to listen to others' points of view and to mobilize others to take a public stand". Online civic engagement can help students to develop online communication and interpersonal skills, as well as critical judgment of online information, centred around the validity and evidence based on the perspectives and views put forward by other people.

Several research studies consistently report that university students at different levels of study (undergraduate, postgraduate and graduate students entering the workplace) may also be lacking important digital skills for their academic studies, for example, on the basis of using tools for conducting advanced/sophisticated online searching (Du and Evans, 2011; Catalano 2013; Cullen et al., 2011; Helms-Park et al., 2007; Martzoukou, 2008). Previous research has found that students transfer information seeking behaviour tactics directly from their everyday life environment, manifested in ways in which for example, they consistently use a single search engine (typically Google or Google Scholar) to search for academic material (Du and Evans, 2011; Catalano, 2013), although more advanced searchers may utilise additional sources as the search progresses (Knight and Pryke, 2012). In addition, research has found that students encounter difficulties on the basis of critical engagement with and evaluation of the quality of the information they retrieve online (Gross and Latham, 2012; Head and Eisenberg, 2009; Catalano, 2013; Wineburg et al., 2016), especially at the stage of entering their academic studies (Callinan, 2005; Mittermeyer, 2005). A number of dispositional factors triggering academic performance have also been explored in the literature (e.g. Poropat, 2009) and a consistent alignment of digital literacy skills with academic success has been noted (Thorne, 2013). Most recently, Gkorezis et al. (2017) have addressed this issue and suggested that information seeking and, in turn, academic self-efficacy, mediate the positive association between students' exploration and academic performance.

Although the challenges that students encounter reported in the above studies cannot be generalised to all students, these findings signify a need to further explore more systematically whether they are rooted to diverse students' previous online digital experiences. Furthermore, we may pose the question of whether these may support or hinder students' digital competences to complete their academic work.

Despite these findings, education curricula have not kept up with such challenges and questions around 'what do students practise at home?' and 'How do they transfer habitual everyday life 
practices and behaviours into the educational environment?' are rarely asked. From that point of view, a different type of digital divide may be emerging. One that points to the lack of digital skills which connect to making good choices and decisions in everyday life.

\section{Mapping Students' Digital Competences}

In relation to the countries of the institutions involved in this research (UK, Ireland and Greece), different projects are currently underway to address some of these directions and challenges raised in this work and various national initiatives explore the need to develop digital literate university students. For example, in the UK JISC has now developed the 'Digital Capability Discovery Tool' which offers an "empowering first step for staff and students to reflect on their digital capabilities and to identify current strengths and areas for development” (JISC, 2019). The tool identifies six composite areas: ICT/digital proficiency, information data and media literacies (critical use), digital creation, problem-solving and innovation (creative production), digital communication, collaboration and participation (participation), Digital learning and development (development) and Digital identity and wellbeing (self-actualising) (JISC, 2019). This shows that there is interest to develop systematic empirical studies at university level to further explore students' digital skills and capabilities. However, the digital citizenship angle may require additional focus, as it may help to explain why particular students may be struggling more than others on the basis of developing more advanced digital competences required in the academic environment.

The Irish National Digital Experience Survey (INDEx), which was launched in 2019 to gather information from students, educators, and institutions about digital literacy, as well as to promote better teaching and learning in higher education (National Forum for the enhancement of Teaching and Learning in Higher Education, 2019). The project is ongoing involving $34 \mathrm{HE}$ institutions and it is supported by the National Forum for the Enhancement of Teaching and Learning in Higher Education, Ireland's key national group for education. This project was recently highlighted for its approach to digital education at the European Commission's ET2020 Working Group on Digital Education: Learning, Teaching and Assessment, held in February 2020 (European Commission, 2020). However, this initiative is still based on ICT skills development and digital learning for “optimizing students' educational experiences" but not also on holistically exploring the everyday life digital competencies students bring into education. Digital learning is therefore defined as "any type of learning that uses, or is accompanied by technology. It includes, but is not limited to, accessing course materials online, reading e-journals, completing online quizzes, and using time management apps, in addition to online lectures and distance-based learning" (National Forum for the enhancement of Teaching and Learning in Higher Education, 2019). 
In Greece, there have been a number of national and EU initiatives aiming to promote digital literacy in education; however, these, mainly, have an emphasis on schools and, again, the introduction of ICTs. Notably two national projects, 'The Digital School I: Digital Educational Platform, Interactive Books and Repository of Learning' (2010-2015), and the 'The Digital School II: Expanding and Exploiting the Digital Educational Platform, Interactive Books and the Repository of Learning' (2015-2020) (Greek Ministry of Education, 2010-5) were both based on the use of digital technologies in the creation of a digital culture in Greek primary and secondary education (Megalou and Kaklamanis, 2014). Greece has a low position (27th out of 28 EU member states) in the Digital Society and Economy Index (DESI), which is "a composite index that summarises relevant indicators on Europe's digital performance and tracks the evolution of EU member states in digital competitiveness" (European Commission, 2019) and measures, among others, Internet connectivity and use and digital skills. As a result, the Greek government is working on a National Digital Policy (2016-21), empowering human resources with digital skills, focusing on supporting research and development, strengthening digital skills at school and placing an emphasis on lifelong learning via actions for example that involve the development of Massive Open Online Courses (MOOC) on ICT (including Open Technologies) available to pupils and students (Ministry of Digital Policy, Telecommunications and Media, 2016), as well as other ICT "related entities aiming to provide every Greek citizen with the opportunity to become a member of the digital society as a digital citizen". At Higher Education level, however, there is little activity in that domain. An example is the work by the Hellenic Open University, currently working on addressing the lack of focus on digital competences with a view to enhancing the digital skills of the Greek population, particularly addressing disadvantaged social groups, including the unemployed and senior citizens (Drigas et al., 2019; p.4).

These approaches emphasize that in Higher Education there is a need to approach digital competences not just from a digital skills angle, which addresses computer or ICT literacy (i.e. focusing on operations and processes, technical knowledge and understanding) but also from a cognitive, social, ethical, behavioural and attitudinal aspect. Therefore, there is a need to understand the diversity of learners and their different digital experiences, practices and mindsets, with a view to understanding how to most effectively help them to develop into the professionals and citizens of the future: those who are committed to life-long learning and have the expected digital behaviours that will help them thrive in a fast-growing online environment. The skills and competencies that people develop are acquired via different contexts, "through primary, secondary and tertiary education, through training, self-directed learning and experience of the workplace or everyday life" (Government Office for Science 2017, p.6). 
In addition, emphasis should be placed not only on students' development but also on educators' development of digital competencies/literacy (across primary, secondary, further and higher education). As Laurillard et al. (2016) note, actions that will support the above developments require the following conditions: “... innovation in pedagogical approaches, developing digital skills as part of the entire curriculum, changing assessment methods to digital forms, supporting digital innovation, updating digital skills of teachers and developing a digital skills policy" (p.4).

\section{Research Aims}

Given the above gaps, debates and areas for further development in Higher Education, the aim of this research is to explore how students in Higher Education self-assess their digital competence/literacy on the basis of two conceptual directions discussed within established theoretical frameworks, which may be summarised as follows:

- technology mastery, i.e. the abilities, competencies, capabilities, and skills required for using digital technology, media and tools

- digital citizenship mindset, which consists of attitudes and behaviours necessary to develop as a critical, reflective and life-long 21 st century learner.

The paper reports on an initial survey that was conducted as part of a larger research project, which is a collaboration between three European universities in Scotland, Ireland and Greece aiming to share cross-institutional knowledge, expertise, practices for the teaching of foundational digital competences at university level, examining the following areas:

- the direction of government and education-based digital competence initiatives and policies in the three countries, addressing students' digital skills gaps in Higher Education.

- the meaning and significance of developing digital competencies for education, everyday life, and work for students.

- the role and contribution of academics and librarians in the development of students' digital knowledge as a synergistic endeavour, working with these educational stakeholders in partnership.

Importantly, this survey examined issues around digital competencies from students' perspectives, taking a snapshot of students' views of their digital competencies to enhance awareness of their significance among students and open up conversations about what digital skills and practices could be embedded into courses. JISC (2017), in an earlier pilot study of the self-assessment "Digital capability discovery tool", used by institutions from higher 
education, found that although strategic priorities and approaches differed, self-assessment was considered by different universities to be a useful platform for discussing digital experiences, practices and needs, raising awareness, auditing and benchmarking practice as well as creating a platform of 'continuum of support'.

Other researchers have used student self-assessment of competencies with successful outcomes. For example, Ciardo et al., (2019) found that dentistry students' self-assessment of competencies for the workplace and learning outcomes were correlated. The ability to selfassess is considered an important skill in health-related fields; in a meta-analysis of thirty-five studies, Blanch-Hartigan (2011) established that medical students are moderately able to selfassess, and are better able to assess their skills as they progress through medical school. While self-assessment may be inaccurate where students feel pressured to protect themselves or where they confuse effort with outcomes (Brown et al., 2015), the survey in this paper was not linked to assessment nor student identities.

\section{Method}

\section{Survey grounding}

A student survey was conducted in order to empirically explore the theoretical perspective discussed in this paper, as supported by two key frameworks: the European Digital Competence Framework for Citizens (Carretero et al., 2017), also known as DigComp and The Digital Capabilities framework, developed by JISC (2012). The survey was also informed by findings of previous academic research emphasizing the impact of the everyday life context on the development of students' information and digital literacy (Martzoukou and Sayyad, 2017) and several other key government level publications (e.g. UK Department of Education, 2019; UK Department for Business Innovation \& Skills and Department for Culture Media \& Sport, 2016).

The survey addressed digital competence/literacy items, based on a critical overview of the above frameworks and government reports which collectively addressed a total of 11 themes (provided in Appendix 1). These are explored both from the technical (ICT competence, handling computers, devices, applications and the Internet) and higher-level competence perspective (critical thinking, reflection and life-long learning, information and data literacy, communication and collaboration, digital content creation, safety and problem solving) discussed earlier. However, it should be noted that although these areas are commonly presented foci in the framework/policy documents which informed this study, they all follow a slightly different approach, order or emphasis in the way in which they approach each item. For example, the Essential Digital Skills Framework developed by the UK Department of 
Education (2019), addresses skills for life and work which include digital foundation skills (similar to ICT proficiency \& productivity such as handling and connecting different devices, understanding the internet, using browsers etc.), communicating (similar to digital communication skills, such as communicate with others digitally using email and other messaging apps and video tools and social media platforms), handling information and content, transacting, problem solving and being safe and legal online. All of these present a similar focus, albeit slightly different sub-categorisations and order of themes.

In addition, differently to this project directions, the framework proposes a separate focus for the work and the everyday life context, with the former perceived as a more formal environment that requires 'more advanced' skills. For example, digital skills for communicating in the work context include 'additional' skills for work such as understanding and conforming with the organisation's IT and social media policies, security protocols and communication policies and overall complying to rules and regulations, whereas digital skills for life are simply focused on using tools and software and not necessarily following rules and regulations which could help people develop attitudes which could inform what they do in the world of work as well (UK Department for Education, 2019). This is also mirrored in other policy documents/frameworks which place emphasis on "building digital skills capacity with industry-relevance" and developing curricula on the basis of Higher Education partnerships with industry, "to provide people with the skills they will need in their roles across the workforce". Here the focus is, again, on "advanced digital skills that will make a difference", as well as on innovation as an essential part of the digital economy:

“... it is not just the 'user' end of skills that is essential, but also the 'innovator' end of skills. Effective skills in using technology, combined with the knowledge and competencies to innovate, can increase the matching of digital skills to the needs of the UK digital economy" (UK Department for Business Innovation \& Skills and Department for Culture Media \& Sport, 2016; p.13).

Nevertheless, previous digital experiences from their everyday life, which may impact upon the developments of these advanced digital skills and innovation, are seldom the focus. Therefore, in addition to the above items the survey included multifaceted items addressing "Everyday participation as digital citizen", which aimed to capture the competence of students on the basis of two choice decision-making mechanisms, i.e. hedonic and utilitarian alternatives (Khan et al., 2005). Hence, we superpose that students' competences level as digital citizens should be treated differently whether their decisions relate to: 
- Hedonic digital competences: Activities centred on emotions and feelings (such as leisure and personal growth/ learning activities), including e-leisure (e.g., playing online games, socialising online) and/or e-learning (e.g., looking for new digital opportunities to grow as a person).

- Utilitarian digital competences: Activities of "practical" nature centred around a task (such as voting or finding information on health), consisting of the following subcategories: e-democracy (e.g., accessing political processes, such as voting, online), e-government (e.g., accessing and using government online services, such as legal and financial information), and e-health (e.g., accessing and using health services online).

Students' hedonic and utilitarian behaviours and aspects have been extensively discussed within the academic learning environment (Huang, 2020). The everyday life dimensions relate to utilitarian and hedonic values of consumption in a broader to education sense (Holbrook and Hirschman, 1982). In this vain utilitarian value is mostly associated with the functional and monetary elements of everyday life; while the hedonic aspect involves social and emotional everyday life dimensions (Prebensen and Rosengren, 2016). In this work, we propose that hedonic and utilitarian behaviours practiced within the everyday life environment are linked with self-perceived technical and higher-level digital competences which should be examined within the continuum of the everyday life and the education related context.

\section{Limitations}

The survey was administered as a tool for critical personal reflection, gauging baseline selfassessed digital competencies with an emphasis on students' transitions from the everyday life environment into the education context. Self-assessment has been previously challenged as a less accurate measurement with, especially, students overestimating their confidence and ability. Other studies have attempted to overcome this limitation by employing different approaches such as using self-assessment and knowledge/skills quizzes to highlight the gap between perceived and actual competency (Kruger and Dunning, 1999). However, overall, the survey objectives of this study were two-fold: to not only act as a basis for empirical data for the theoretical propositions of the research but also to provide an evidence base for initiating discussions with other academics, librarians and learning support professionals centered on a cross-institutional approach for the teaching of digital competences at university level. Although it is likely that some students may have overrated their competences in some areas, high competence indicated by students, especially in areas where is it not naturally expected, may offer a basis for further research and critical discussion. Equally, lower values may indicate areas which require even more additional support than the actual outcome may suggest. 
Furthermore, this study is restricted to a narrow group of students studying for a specific subject and within the context of a limited number of European institutions which may not present similar opportunities and challenges as in other universities. The results may therefore be generalized with caution, given the weakness in methodology. However, they present a starting point for follow up search and debate on the basis of student digital competence diversity that may be encountered and the learning interventions that could be designed. The study also presents a methodology for follow up research which could lead to a better understanding of how everyday life digital experiences may play a role in how students learn in digital rich and changing university educational environments.

\section{Survey administration}

The survey took place during 2018/2019 academic year, and included Library and Information Science students from three Higher Education institutions, located in different European countries: The Ionian University (Greece), University College Dublin (Ireland) and Robert Gordon University in Aberdeen (Scotland). All three institutions offer a well-established portfolio of taught and research programmes in the field of Library and Information Science:

- The Department of Archives, Library Science and Museology, School of Information and Informatics, at the Ionian University, offer undergraduate and postgraduate courses over the last few decades. For the survey undergraduate students of the third and fourth year who had completed the Information Seeking and User Studies course were asked to participate, as well as M.Sc. students in the first year of Management of Cultural Information. These include a total of 20 postgraduate students and a total of around 207 undergraduate students.

- The School of Information and Communication Studies in the College of Social Sciences \& Law (CoSSL), University College Dublin offers both postgraduate and undergraduate programmes in a range of subject areas. For this project, undergraduate students taking the second-year module DigiComp: Core Competencies for Digital Citizenship, as well as postgraduate students on the Master of Library and Information Studies programme were invited to participate in the project survey. Therefore, a total of 27 postgraduate students included in the survey along with a total of 69 undergraduate students.

- The School of Creative and Cultural Business in Aberdeen, Scotland offers postgraduate programmes in Information and Library Studies and Information Management and students studying in these two programmes, and were taking/had taken a first-year module on Information Seeking and Use were invited to participate in the project survey, i.e. a total of 87 postgraduate students. 
The survey distribution approach adopted for gathering data across institutions involved administrating a questionnaire which was rolled out online via JISC's Online Surveys software. An online survey has many advantages, in the present case enabling access to geographically dispersed populations and facilitating the collection and collation of data easily. Loomis and Paterson (2018) have observed that online surveys further offer cost effective data collection, faster dissemination and response rates, as well as computerised data collection, entry, and analyses. While the response rates for online surveys may be considered lower than for mailed surveys, Loomis and Paterson (2018) found that the two modes of survey distribution had comparable response rates.

The survey questionnaire was initially tested out with small groups of students from each institution to explore the time taken to complete it, the survey instructions, the demographic categories and the structure of the questions. No major problems were identified and only minor adjustments were made to some of the questions, adding, for instance, more examples to illustrate the ICT Proficiency section, and slightly amending the terminology used in one of the questions addressing scholarly and web resources.

\section{Questionnaire development}

As it has already pointed out, the questionnaire structure was grounded on both the European Digital Competence Framework for Citizens (Carretero et al., 2017) and the Digital Capabilities framework, developed by JISC (2012). These have been further elucidated on the basis of their construct-specific items for university settings. Exploratory analysis strengthening the theoretical approach of JISC took place mapping specific items against other existing frameworks, within each thematic area. For example, the construct of 'Information, media and data literacy' appears in other frameworks, such as SCONUL 7 pillars of information literacy, UNESCO MIL, Open University DIL framework, A New Curriculum for Information Literacy (ANCIL) and Vitae RDF (information lens) among others (JISC, 2015b).

Table 1. Structure and dimensions of the questionnaire developed for the survey

\begin{tabular}{|c|l|}
\hline Questionnaire Dimensions & \multicolumn{1}{c|}{ Dimension study items } \\
\hline $\begin{array}{c}\text { Q.1 Demographics (Items } \\
\mathbf{N}=\mathbf{6})\end{array}$ & Sex, Age, Country of residence, Marital Status, Current level of Study, Year of Study \\
\hline $\begin{array}{c}\text { Q.2 Everyday participation } \\
\text { as a digital citizen (Items } \\
\mathbf{N}=\mathbf{5})\end{array}$ & $\begin{array}{l}\text { Utilitarian and hedonic everyday-life activities (e-democracy, e-government, e-health, e-leisure, e- } \\
\text { learning) }\end{array}$ \\
\hline
\end{tabular}




\begin{tabular}{|c|c|}
\hline $\begin{array}{l}\text { Q.3 ICT Proficiency with } \\
\text { completing different tasks } \\
\quad \text { (Items N=7) }\end{array}$ & $\begin{array}{l}\text { Technological devices, Software, Web browsers, Search engines, University digital administrative } \\
\text { services, University learning management systems, Personal digital services }\end{array}$ \\
\hline $\begin{array}{l}\text { Q.4 ICT productivity } \\
\quad(\text { Items } \mathrm{N}=3 \text { ) }\end{array}$ & $\begin{array}{l}\text { Organising, managing, storing, and sharing digital files for your learning through Internet spaces and/or } \\
\text { your university's online systems, Selecting software and apps matched to tasks, Using tools, such as } \\
\text { calendars, task lists, project and time management apps, to make learning more efficient }\end{array}$ \\
\hline $\begin{array}{l}\text { Q.5 Information } \\
\text { identification in different } \\
\text { contexts (Items } \mathrm{N}=3 \text { ) }\end{array}$ & Scholarly literature, Professional literature, Popular information \\
\hline $\begin{array}{l}\text { Q.6 Information Literacy } \\
\text { skills (Items } \mathrm{N}=7 \text { ) }\end{array}$ & $\begin{array}{l}\text { Finding digital information relevant to your academic studies, using informal Web sources, Finding } \\
\text { digital information relevant to your academic studies, using scholarly sources, Using online collection } \\
\text { tools for gathering digital information together in new ways, Evaluating whether digital information is } \\
\text { trustworthy and relevant, Organising the digital information you find for your learning through folders, } \\
\text { bookmarks, reference management software, and tagging, Referencing digital information sources, } \\
\text { adhering to a referencing style, Understanding how to share information publicly online, respecting and } \\
\text { acknowledging the work of others }\end{array}$ \\
\hline $\begin{array}{l}\text { Q.7 Digital creation skills } \\
\text { (Items } \mathrm{N}=4 \text { ) }\end{array}$ & $\begin{array}{l}\text { Designing new digital content, Capturing, editing, and producing digital media, Creating, sharing, and } \\
\text { showcasing digital artefacts, with audience and purpose in mind, Coding and designing apps, digital } \\
\text { games, virtual environments, and interfaces }\end{array}$ \\
\hline $\begin{array}{l}\text { Q.8 Digital research skills } \\
\text { (Items } \mathrm{N}=8 \text { ) }\end{array}$ & $\begin{array}{l}\text { Finding digital research data online, Collecting data using digital tools relevant to your subject area, } \\
\text { Designing and administering data collection instruments online, Organising and storing digital research } \\
\text { data, Analysing digital research data using simple tools, Interpreting digital data for research purposes, } \\
\text { Understanding how data are used to construct arguments, make decisions, and/or solve problems, } \\
\text { Following ethical, legal, and security guidelines when using research data }\end{array}$ \\
\hline $\begin{array}{l}\text { Q.9 Digital communication } \\
\text { skills (Items } \mathbf{N}=6 \text { ) }\end{array}$ & $\begin{array}{l}\text { Participating in a range of digital networks related to your interests, work, and/or academic subject, } \\
\text { Understanding acceptable ways of interacting in particular digital contexts, Communicating respectfully } \\
\text { and inclusively, recognising that digital media can be used to intimidate, shame, and harass other people, } \\
\text { Recognising false or damaging digital communications, Sharing any specialist ideas, Designing digital } \\
\text { communications for different purposes }\end{array}$ \\
\hline $\begin{array}{l}\text { Q.10 Digital innovation } \\
\text { (Items } \mathbf{N}=2 \text { ) }\end{array}$ & $\begin{array}{l}\text { Developing new ideas and projects using digital technologies, Promoting new digital tools and } \\
\text { opportunities to others }\end{array}$ \\
\hline $\begin{array}{l}\text { Q.11 Digital learning and } \\
\text { development (Items } \mathrm{N}=8 \text { ) }\end{array}$ & $\begin{array}{l}\text { Participating in digital learning opportunities and resources, Adopting new ways of learning online, } \\
\text { Working collaboratively and supportively with other learners, using digital technologies where } \\
\text { appropriate, Using digital tools to take notes, annotate, collate and curate learning materials, review, and } \\
\text { revise learning, Using digital tools to record learning events/outcomes and use them for self-analysis, } \\
\text { reflection, and showcasing of achievement, Receiving and responding to digital feedback about your } \\
\text { academic work, Managing your engagement and participation in digital learning environments, Sharing } \\
\text { your digital know-how and digitally guide other learners }\end{array}$ \\
\hline $\begin{array}{l}\text { Q.12 Digital abilities to } \\
\text { complete academic work } \\
\quad(\text { Items } \mathbf{N}=1)\end{array}$ & Which level best describes your digital abilities to complete your academic work? \\
\hline $\begin{array}{l}\text { Q.13 Digital identity } \\
\text { management (Items } N=6 \text { ) }\end{array}$ & $\begin{array}{l}\text { Managing your online profiles on different digital media in a way that is suitable for personal, } \\
\text { professional, and academic purposes, Understanding how your online personal data are collected and } \\
\text { used in different systems and use privacy settings appropriately, Being aware of the potential positive or } \\
\text { negative impact of what you communicate online on your digital reputation, Making sure outcomes of } \\
\text { learning and other achievements are accessible in digital forms, Analysing your digital impact, footprint, } \\
\text { and reputation using analytics or other digital tools, Linking and curating personal identities }\end{array}$ \\
\hline $\begin{array}{l}\text { Q.14 Digital wellbeing } \\
\text { (Items } \mathbf{N}=6 \text { ) }\end{array}$ & $\begin{array}{l}\text { Feeling comfortable, in control, and safe when using digital technologies, Recognising that digital } \\
\text { information and media can cause distraction, overload, and stress, and disconnecting when necessary, } \\
\text { Considering the rights and wrongs and the possible consequences of your online behaviour, Acting } \\
\text { positively against cyber bullying and other damaging online behaviours, Using digital media to access } \\
\text { services, monitor health conditions, and participate in the community, Managing online and real-world } \\
\text { interactions in ways that support healthy relationships }\end{array}$ \\
\hline
\end{tabular}


In the demographics, it should be pointed out that the student age groupings were portrayed on the basis of the Pew Research Centre categorizations as follows (Dimock, 2019): 1. Generation Z (born 1997-2012): 18-22 years old; 2. Millennial generation (born 1981 -1996): 23-38 years old; 3. Generation X (born 1965-1980): $39-54$ years old; 4. Baby Boomer (born 1946-1964) => 55 years old.

In order to assess the closed-ended questions, the survey measurement scale was based on a five-point Likert type scale of digital competence which represented different levels of knowledge and self-sufficiency on the basis of performing specific digital tasks, described as follows:

Level (1): Novice indicating "the digital task is new to me. I am currently developing basic knowledge and skills in this area, but I need help either to complete or to learn how to complete this sort of task".

Level (2): Basic indicating "I have foundational knowledge in this area. I can perform simple digital tasks with help from others".

Level (3): Intermediate indicating "I have more than foundational knowledge, but I am not yet advanced in this area. I can usually complete complex digital tasks independently, although I sometimes need help from someone more advanced than I am.”

Level (4): Advanced indicating "I have advanced knowledge in this area, though I am not an expert. I can perform complex digital tasks without assistance. I adapt easily to learning new knowledge and skills. Others sometimes ask me for help."

Level (5): Expert indicating "I have mastered the knowledge and skills for this area. I apply my knowledge and skills to create and redesign processes, tools, and/or technologies appropriately and effectively. As an expert in this area, I frequently show others how to complete these tasks."

The measurement scale was accommodated and explained within each closed-ended question dimension of the survey. The participants were prompted to read, understand and confirm their understanding of both the survey rationale as well as the above scale levels prior to proceeding with completing the survey questionnaire. Finally, a series of open-ended questions were added to further explore the previous learning experiences of participants around the development of digital competencies in the context of everyday life learning and current education. These explored, how participants had developed digital skills needed to participate effectively in digital citizenship activities, and how they had developed ICT Proficiency skills for completing different digital tasks (e.g. at work, at home, via training etc). 


\section{Ethics}

The proposed research agenda (survey methodology and questionnaire) was approved separately by each of the corresponding participating institutions. At the Ionian University the ethics of the research were formally accepted by the departmental committee of Archives, Library Science and Museology. At the School of Creative and Cultural Business the work was approved following the Research Ethics Policy of the university (the Research Ethics SelfAssessment - RESA - process). At University College Dublin, the proposed research was submitted to the Research Ethics Committee who approved an ethics exemption. Furthermore, the survey was administered using JISC's 'Online Surveys', which is a General Data Protection Regulation (GDPR) approved too.

\section{Statistical Analysis Methodology}

For the statistical analysis the SPSS version 25.0 statistical package was employed. Prior to proceeding any further the overall and the constructs' scale reliability were assessed for internal consistency with Cronbach's alpha reliability coefficient. Descriptive statistics took place in order to report the results (frequencies, valid percentages, median, mode etc.) on students' demographics and self-assessed digital competences. Thereafter, Kolmogorov-Smirnov and Shapiro-Wilk Normality tests at Sig. $<0,05$ level took place, and as expected, the questionnaire study items did not follow the normal distribution. Therefore, non-parametric statistical tests were performed, i.e. Mann-Whitney U-test for assessing statistically significant differences between two independent subgroups and Kruskal-Wallis H-test one-way analysis of variance by ranks for assessing differences among more than two independent subgroups. Moreover, Exploratory Factor Analysis (EFA) was employed through Principal Components Methods (PCA) and Varimax orthogonal rotation method for grouping the variables for each of the questionnaire constructs. Finally, bivariate Pearson's correlation statistics are reported for all grouped variables.

\section{Results}

\section{Reporting scale internal consistency}

The overall internal consistency of all variables included in the survey constructs was estimated through Cronbach's alpha coefficient to be 0.973 . The reliability properties of all measurement questionnaire constructs of all the items composing the constructs are reported in Table 2. The internal consistency expressed by Cronbach's alpha reliability coefficient for all constructs was found to be quite adequate with no problematic variables identified through scale if an item delated Cronbach's alpha coefficient estimates. 
Table 2. Questionnaire construct reliability

\begin{tabular}{|l|c|}
\hline \multicolumn{1}{|c|}{ Questionnaire Constructs } & Reliability (Cronbach's alpha) \\
\hline Everyday participation as a Digital Citizen (Items N=5) & 0.76 \\
\hline ICT Proficiency with completing different tasks (Items N=7) & 0.90 \\
\hline ICT productivity (Items N=3) & 0.84 \\
\hline Information identification in different contexts (Items N=3) & 0.86 \\
\hline Information Literacy skills (Items N=7) & 0.86 \\
\hline Digital creation skills (Items N=4) & 0.85 \\
\hline Digital research skills (Items N=8) & 0.89 \\
\hline Digital communication skills (Items N=6) & 0.84 \\
\hline Digital innovation (Items N=2) & 0.87 \\
\hline Digital learning and development (Items N=8) & 0.92 \\
\hline Digital identity management (Items N=6) & 0.85 \\
\hline Digital wellbeing (Items N=6) & 0.86 \\
\hline
\end{tabular}

\section{Demographics}

Table 3 summarises the demographic characteristics of the participants, according to "sex", "age", "country of residence", "marital status", "current level of study", and "year of study". After data screening of the survey responses, four (4) questionnaires were removed and 164 undergraduate and postgraduate students from all institutions were included in the sample. Table 2 provides in detail the survey demographics which may be summarized as follows: $38.6 \%$ of the participants were postgraduate students residing in Scotland, Ireland and Greece (11.0\% and $10.4 \%$ and $17.2 \%$ respectively); a total of $49.7 \%$ were undergraduate students residing in Greece, while $11.7 \%$ were international postgraduate students), single (71,6\%), female (79.3\%) and post-millennials (49.1\%); while $31.3 \%$ were millennials and $19.6 \%$ belonged to Generation X.

Table 3. Survey Demographics

\begin{tabular}{|c|c|c|c|}
\hline Q1. Demographics & Variables & Respondents & Percentage \\
\hline \multirow{3}{*}{ Sex (valid N=164) } & Male & 34 & $20.7 \%$ \\
\cline { 2 - 4 } & Female & 130 & $79.3 \%$ \\
\hline \multirow{3}{*}{\begin{tabular}{c} 
Age (valid N=163) \\
\cline { 2 - 4 }
\end{tabular}} & $\begin{array}{c}18-22 \text { years old (Generation Z, Post- } \\
\text { millennials) }\end{array}$ & 80 & $49.1 \%$ \\
\cline { 2 - 4 } & $23-38$ years old (Millennials) & 51 & $31.3 \%$ \\
\hline \multirow{2}{*}{$\begin{array}{c}\text { Country of } \\
\text { residence (valid } \\
\text { N=163) }\end{array}$} & 39-54 years old (Generation X) & 32 & $19.6 \%$ \\
\cline { 2 - 4 } & Great Britain & 109 & $66.9 \%$ \\
\cline { 2 - 4 } & Greece & 17 & $10.4 \%$ \\
\hline
\end{tabular}




\begin{tabular}{|c|c|c|c|}
\hline & Other & 19 & $11.7 \%$ \\
\hline \multirow{2}{*}{$\begin{array}{l}\text { Marital Status } \\
\text { (valid } \mathrm{N}=162 \text { ) }\end{array}$} & Single, Widowed, Divorced/Separated & 116 & $71.6 \%$ \\
\hline & Married/Domestic partnership & 46 & $28.4 \%$ \\
\hline \multirow{2}{*}{$\begin{array}{l}\text { Current level of } \\
\text { Study (valid } \\
\mathrm{N}=158 \text { ) }\end{array}$} & $\begin{array}{l}\text { University Studies (3 years or longer: e.g. BA, } \\
\text { BEd, BSc) }\end{array}$ & 97 & $61.4 \%$ \\
\hline & $\begin{array}{l}\text { Postgraduate Studies (MA, MSc) / } \\
\text { Doctoral/Research Studies }\end{array}$ & 61 & $38.6 \%$ \\
\hline \multirow{2}{*}{$\begin{array}{l}\text { Year of Study } \\
\text { (valid } \mathrm{N}=155 \text { ) }\end{array}$} & 1st year & 89 & $57.4 \%$ \\
\hline & 2nd, 3rd, 4th, 5th and more & 66 & $42.6 \%$ \\
\hline
\end{tabular}

Table 4 summarises the results of the participants' self-assessed competences in regard to “everyday participation as a Digital Citizen", i.e. digital citizen competences for e-democracy, e-government, e-health, e-leisure, and e-learning. Evidently, the survey participants felt more competent in regard to e-leisure (median 4.0) and e-learning digital citizenship activities (median 3.0). The indices (explained at the last row of Table 4) indicate statistically significant differences with sample demographics subgroups. Focusing on the age groups it is noted that there are significant differences for all the items of everyday life participation competences. These, however, mainly result from differences between the post millennials (18-21 years old) and the other two student age group categories.

Table 4. Self-assessed competences for everyday life participation as digital citizens

\begin{tabular}{|c|c|c|c|c|c|c|c|}
\hline \multirow{2}{*}{\multicolumn{2}{|c|}{$\begin{array}{l}\text { Q.2 "Please rank your everyday life } \\
\text { participation competences as a Digital } \\
\text { Citizen for the following activities": }\end{array}$}} & \multicolumn{6}{|c|}{$\begin{array}{l}\text { Competences Level Scale } \\
2=\text { Basic, } 3=\text { Intermediate, } 4=\text { Advanced, } 5= \\
\text { Expert }\end{array}$} \\
\hline & & 1 & 2 & 3 & 4 & 5 & Median \\
\hline 1 & e-democracy (valid $\mathrm{N}=160)^{\alpha, \gamma, \mu, \lambda, v}$ & $\begin{array}{c}75 \\
(46,9 \%)\end{array}$ & $\begin{array}{c}33 \\
(20,6 \%)\end{array}$ & $\begin{array}{c}27 \\
(16,9 \%)\end{array}$ & $\begin{array}{c}19 \\
(11,9 \%)\end{array}$ & $\begin{array}{c}6 \\
(3,8 \%)\end{array}$ & 2,00 \\
\hline 2 & e-government (valid $\mathrm{N}=162)^{\alpha, \gamma, \mu, \lambda, v}$ & $\begin{array}{c}61 \\
(37,7 \%)\end{array}$ & $\begin{array}{c}30 \\
(18,5 \%)\end{array}$ & $\begin{array}{c}34 \\
(21 \%)\end{array}$ & $\begin{array}{c}33 \\
(20,4 \%)\end{array}$ & $\begin{array}{c}4 \\
(2,5 \%)\end{array}$ & 2,00 \\
\hline 3 & e-health (valid $\mathrm{N}=163)^{\sigma, \alpha, \gamma, \mu, \lambda, v}$ & $\begin{array}{c}38 \\
(23,3 \%)\end{array}$ & $\begin{array}{c}45 \\
(27,6 \%)\end{array}$ & $\begin{array}{c}42 \\
(25,8 \%)\end{array}$ & $\begin{array}{c}35 \\
(21,5 \%)\end{array}$ & $\begin{array}{c}3 \\
(1,8 \%)\end{array}$ & 2,00 \\
\hline 4 & e-leisure (valid $\mathrm{N}=164)^{\sigma, \alpha}$ & $\begin{array}{c}13 \\
(7,9 \%)\end{array}$ & $\begin{array}{c}17 \\
(10,4 \%)\end{array}$ & $\begin{array}{c}38 \\
(23,2 \%)\end{array}$ & $\begin{array}{c}64 \\
(39 \%)\end{array}$ & $\begin{array}{c}32 \\
(19,5 \%)\end{array}$ & 4,00 \\
\hline 5 & e-learning (valid $\mathrm{N}=163)^{\alpha, \gamma, \mu, \lambda}$ & 9 & 22 & 61 & 52 & 19 & 3,00 \\
\hline
\end{tabular}




\begin{tabular}{|l|l|c|c|c|c|c|}
\hline & $(5,5 \%)$ & $(13,5 \%)$ & $(37,4 \%)$ & $(31,9 \%)$ & $(11,7 \%)$ & \\
\hline
\end{tabular}

\section{Survey results of self-assessed competences for digital citizenship constructs}

The descriptive statistics and statistically significant differences for all group demographics with the items of the survey constructs are summarized in Appendix I (Table 1 to Table 12). Students assessed themselves as "intermediate" (median=3.00) in the majority of the survey constructs and their overall self-perceived digital competences to complete their academic work. More specifically, utilitarian and hedonic based activities such as "e-leisure" (median=4.00) and "e-learning" (median=3.00) were high self-perceived competences for the participants in the "Everyday participation as a Digital Citizen" category. Although the significant sub-group statistics are identified through K-W and M-W tests in the relevant tables of Appendix I, some statistical significance differences among the different age group categories for participants' self-reported competences are further reported here (it should be noted that statistical differences are reported in the tables of results as superscripts, however, the mean ranks reported by the rank-based nonparametric K-W and M-W tests indicate the direction of the differences between the distinct subgroups examined): a) "e-democracy", $p<0.05$, with a mean rank score of 56.61 for Post-millennials, 99.56 for Millennials and 107.31 for Generation X (i.e. the recorded self-perceived competence for Generation X age group is higher than the other two), b) "e-government", $\mathrm{p}<0.05$, with a mean rank score of 50.22 for Post-millennials, 104.21 for Millennials and 119.03 for Generation X (i.e. the recorded selfperceived competence for Generation X age group is higher than the other two), c) "e-health", $\mathrm{p}<0.05$, with a mean rank score of 56.04 for Post-millennials, 108.68 for Millennials and 101.03 for Generation X (i.e. the recorded self-perceived competence for Millennials age group is higher than the other two), d) "e-leisure", $\mathrm{p}<0.05$, with a mean rank score of 79.90 for Postmillennials, 95.85 for Millennials and 65.17 for Generation X (i.e. the recorded self-perceived competence for Millennials age group is higher than the other two), and e) "e-learning", $\mathrm{p}<0.05$, with a mean rank score of 67.97 for Post-millennials, 96.30 for Millennials and 91.30 for Generation X (i.e. the recorded self-perceived competence for Millennials age group is higher than the other two).

In the case of IT proficiency, the use of all tools "Technological devices", "Web browsers", "Search engines", "University digital administrative services", "University learning management systems" (median=4.00) and "Software" (median=3.00) received higher selfperceived competences. 
Students assessed themselves as "intermediate" (median=3.00) in the self-perceived competences of "Information Literacy skills" and "Digital learning and development". Statistical significance differences are provided among the different age group categories. Participants' self-reported competences for a) "Finding digital information relevant to your academic studies, using informal Web sources" ( $\mathrm{p}<0.05$, with a mean rank score of 67.72 for Post-millennials, 95.37 for Millennials and 94.23 for Generation X ( i.e. the recorded selfperceived competences for Millennials age group is higher than the other two), b) "Finding digital information relevant to your academic studies, using scholarly sources" $(\mathrm{p}<0.05$, with a mean rank score of 69.34 for Post-millennials, 95.53 for Millennials and 89.79 for Generation $\mathrm{X}$ ( i.e. the recorded self-perceived competences for Millenials age group is higher than the other two), c) "Evaluating whether digital information is trustworthy and relevant" ( $\mathrm{p}<0.05$, with a mean rank score of 65.88 for Post-millennials, 95,19 for Millennials and 97.13 for Generation X ( i.e. the recorded self-perceived competences for Generation X age group is higher than the other two), d) "Organising the digital information you find for your learning through folders, bookmarks, reference management software, and tagging” ( $\mathrm{p}<0.05$, with a mean rank score of 68.41 for Post-millennials, 97.25 for Millennials and 86,97 for Generation $\mathrm{X}$ (i.e. the recorded self-perceived competences for Millennials age group is higher than the other two), e) "Referencing digital information sources, adhering to a referencing style" $\mathrm{p}<0.05$, with a mean rank score of 61.42 for Post-millennials, 99.77 for Millennials and 100.02 for Generation X i.e. the recorded self-perceived competences for Generation X age group is higher than the other two), f) "Understanding how to share information publicly online, respecting and acknowledging the work of others" ( $<<0.05$, with a mean rank score of 67.41 for Post-millennials, 90.56 for Millennials and 88.02 for Generation X (i.e. the recorded selfperceived competences for Millennials age group is higher than the other two), g) "Participating in digital learning opportunities and resources" $\mathrm{p}<0.05$, with a mean rank score of 68.18 for Post-millennials, 95.46 for Millennials and 90,05 for Generation X ( i.e. the recorded self-perceived competences for Millennials age group is higher than the other two), h) “Adopting new ways of learning online”, $\mathrm{p}<0.05$, with a mean rank score of 64.65 for Postmillennials, 95.49 for Millennials and 95.27 for Generation X (i.e. the recorded self-perceived competences for Millennials age group is higher than the other two), i) "Receiving and responding to digital feedback about your academic work" $\mathrm{p}<0.05$, with a mean rank score of 62.15 for Post-millennials, 100.00 for Millennials and 95.81 for Generation X, i.e. the recorded self-perceived competences for Millennials age group is higher than the other two), and j) "Managing your engagement and participation in digital learning environments" $(\mathrm{p}<0.05$, with a mean rank score of 63.92 for Post-millennials, 97.43 for Millennials and 90.35 for Generation X, i.e. the recorded self-perceived competences for Millennials age group is higher than the other two). 
Furthermore, students assessed themselves as "advanced" (median=4.00) and "intermediate" (median=3.00) in the majority of self-perceived competences of "Digital wellbeing". More specifically, digital wellbeing activities were "advanced" self-perceived competences for the participants in the "Recognising that digital information and media can cause distraction, overload, and stress, and disconnecting when necessary", "Considering the rights and wrongs and the possible consequences of your online behaviour", "Acting positively against cyberbullying and other damaging online behaviours" (median=4.00), and "intermediate" selfperceived competences for the participants in the "Feeling comfortable, in control, and safe when using digital technologies", "Using digital media to access services, monitor health conditions, and participate in the community", "Managing online and real-world interactions in ways that support healthy relationships" (median=3.00).

\section{Grouping variables}

Exploratory factor analysis (EFA) and principal components analysis (PCA) are commonly employed for reducing the number of variables used in a measurement scale (e.g., a questionnaire) and for assessing whether all the variables initially included in a questionnaire are in fact representative of each of the underlying construct (Table 5). PCA transforms a set of variables into a smaller set of variables, called "principal components", which account for most of the variance in the original variables (Comrey and Lee, 1992). PCA with Varimax rotation was employed for grouping the digital competence constructs, presented above. KMO and Bartlett Test of Sphericity were employed and indicated that it was possible to proceed with principal components factor analysis (Tabachnick and Fidell, 2007). The output of this process is presented in Appendix II. Evidently, each of the survey constructs were grouped to a single component, while the single-item factor loadings were quite high.

As can be seen in Table 5, rows with the descriptive statistics, the participants reported higher competences for the "Everyday participation as a Digital Citizen on hedonic based activities" (mean=3.41) than the lower "Everyday participation as a Digital Citizen on utilitarian based activities" (mean=2.29). Furthermore, it is worth noting that the participants reported low competences for "Digital creation skills" (mean=2.24) and "Digital innovation" (mean=2.51). 
Table 5. Correlations between different grouped variables

\begin{tabular}{|c|c|c|c|c|c|c|c|c|c|c|c|c|c|c|}
\hline \multicolumn{15}{|c|}{ Correlations } \\
\hline Factors & 1 & 2 & 3 & 4 & 5 & 6 & 7 & 8 & 9 & 10 & 11 & 12 & 13 & 14 \\
\hline $\begin{array}{l}\text { 1. Everyday participation as a Digital } \\
\text { Citizen on utilitarian based activities } \\
(\mathrm{N}=164)\end{array}$ & 1 & & & & & & & & & & & & & \\
\hline $\begin{array}{l}\text { 2. Everyday participation as a Digital } \\
\text { Citizen on hedonic based activities } \\
(\mathrm{N}=164)\end{array}$ & 350 & 1 & & & & & & & & & & & & \\
\hline $\begin{array}{l}\text { 3. ICT Proficiency with completing } \\
\text { different tasks }(\mathrm{N}=164)\end{array}$ & $215^{*}$ & $.598^{* * *}$ & 1 & & & & & & & & & & & \\
\hline 4. ICT Productivity ( $\mathrm{N}=164)$ & $.371^{* *}$ & $.504^{*+4}$ & $.655^{\text {*t+ }}$ & 1 & & & & & & & & & & \\
\hline $\begin{array}{l}\text { 5. Information identification in different } \\
\text { contexts }(\mathrm{N}=163)\end{array}$ & $.571^{*}$ & $.544^{* * *}$ & $.409^{*+*}$ & $.561^{* *}$ & 1 & & & & & & & & & \\
\hline 6. Information Literacy skills $(\mathrm{N}=163)$ & $.481^{* * 4}$ & $.516^{* *}$ & $.581^{* * *}$ & $.713^{\text {**t }}$ & $.762^{* *}$ & 1 & & & & & & & & \\
\hline 7. Digital creation skills $(\mathrm{N}=163)$ & $.251^{*}$ & $.435^{* * 1}$ & $.403^{* *}$ & $.554^{*}$ & $.424^{* *}$ & $.484^{* *}$ & 1 & & & & & & & \\
\hline 8. Digital research skills $(\mathrm{N}=163$ ) & $.409^{* *}$ & $.554^{* x}$ & $.516^{* * t}$ & $.672^{* * 4}$ & $.668^{* * *}$ & $.743^{* * *}$ & $.593^{* *}$ & 1 & & & & & & \\
\hline $\begin{array}{l}\text { 9. Digital communication skills } \\
(\mathrm{N}=163)\end{array}$ & $.430^{*+4}$ & $.617^{* *}$ & $.551^{* * *}$ & .656 ** & $.633^{* * *}$ & $.684^{* * *}$ & $.527^{* *}$ & $.742^{* *}$ & 1 & & & & & \\
\hline 10. Digital innovation $(\mathrm{N}=159)$ & .160 & $.349^{* *}$ & $.348^{* *}$ & $.423^{\text {**t }}$ & $.350^{* *+}$ & .360 & $.489^{* *}$ & $.607^{*}$ & $.538^{* *+}$ & 1 & & & & \\
\hline $\begin{array}{l}\text { 11. Digital learning and development } \\
(\mathrm{N}=163)\end{array}$ & $.498^{* x}$ & $.552^{* * *}$ & $.480^{* * *}$ & $.655^{* *}$ & $.645^{* *}$ & $.681^{* * *}$ & $.638^{* *}$ & $.719^{* *}$ & $.747^{* *}$ & $.598^{* *}$ & 1 & & & \\
\hline $\begin{array}{l}\text { 12. Digital abilities to complete } \\
\text { academic work }(\mathrm{N}=161)\end{array}$ & $360^{* *}$ & $.503^{* * *}$ & $.457^{* *+}$ & $.639^{* *}$ & $.598^{* *}$ & $.639^{* * *}$ & $.556^{* *}$ & $.710^{* * *}$ & $.658^{* *}$ & $.483^{* *}$ & $.771^{* *+}$ & 1 & & \\
\hline $\begin{array}{l}\text { 13. Digital identity management } \\
(\mathrm{N}=163)\end{array}$ & $280^{* * 4}$ & $.531^{* * *}$ & $.564^{* * t}$ & $.649^{* *}$ & $.489^{* *}$ & $.599^{* * *}$ & $.503^{* *}$ & $.607^{* * *}$ & $.685^{* *}$ & $.433^{* * *}$ & $.632^{* *}$ & $.524^{* * *}$ & 1 & \\
\hline 14. Digital wellbeing $(\mathrm{N}=163)$ & $352^{* * 4}$ & $.587^{* *}$ & $.601 *$ & .552 ** & $.481^{* *}$ & $.571^{* * *}$ & $.419^{* *}$ & $.594^{*}$ & $.693^{\text {**t. }}$. & $.406^{* *}$ & $.595^{* *}$ & $.476^{* *+}$ & $.742^{*+1}$ & 1 \\
\hline **. Correlation is signif & icant a & the 0 . & 01 leve & el (2-ta & iiled). & *. Con & relatio & $n$ is sig & gnifi & ant at $t$ & the 0.05 & 5 leve & 1(2-tai & iled) \\
\hline Mean & 2.29 & 3.41 & 3.72 & 3.06 & 2.94 & 2.95 & 2.24 & 2.81 & \begin{tabular}{|l|}
3.12 \\
\end{tabular} & 2.51 & 2.77 & \begin{tabular}{|l|}
2.97 \\
\end{tabular} & 2.94 & 3.51 \\
\hline Std. Deviation & 1.02 & .938 & .749 & .862 & .978 & .805 & .880 & .829 & \begin{tabular}{|l|l|}
.798 \\
\end{tabular} & 1.02 & .896 & 1.01 & .797 & .776 \\
\hline
\end{tabular}




\section{Correlation Statistics}

Pearson correlation coefficients and the corresponding significance levels for all the construct components are presented in Table 5 with Pearson's test (2-tailed) at significance level $\mathrm{p}$ $<0.05\left(^{*}\right)$ and significance level $\mathrm{p}<0.01\left(^{* *}\right)$. The descriptive statistics (mean and standard deviation) of the examined constructs for the entire sample are presented in the last two rows of Table 5. It is worth noting that moderate and strong statistically significant correlations were identified between self-reported competences for utilitarian "Everyday Participation as a Digital Citizen on utilitarian based activities" and hedonic "Everyday Participation as a Digital Citizen on hedonic based activities" everyday life participation with all the remaining survey components. For instance, it can be observed that strong (r-value above 0.5) positive correlations are identified for self-reported competences for "Everyday Participation as a Digital Citizen on utilitarian activities" and "Information identification in different contexts" $(\mathrm{r}=.571, \mathrm{p}<0.01)$, "Digital learning and development" $(\mathrm{r}=.498, \mathrm{p}<0.01)$, and "Information Literacy skills" $(\mathrm{r}=.481, \mathrm{p}<0.01)$. In a similar manner significant strong positive correlations (r-value above 0.5) are identified for self-reported competences of "Everyday participation as a Digital Citizen on hedonic based activities" with almost all dimensions of students' digital citizenship recorded competences (i.e. "ICT Proficiency with completing different tasks" $(\mathrm{r}=.598, \mathrm{p}<0.01)$, "ICT Productivity" $(\mathrm{r}=.504, \mathrm{p}<0.01)$, "Information identification in different contexts" ( $\mathrm{r}=.544, \mathrm{p}<0.01)$, "Information Literacy skills" $(\mathrm{r}=.516, \mathrm{p}<0.01)$, "Digital research skills" ( $\mathrm{r}=.554, \mathrm{p}<0.01)$, "Digital communication skills" $(\mathrm{r}=.617, \mathrm{p}<0.01)$, "Digital learning and development" $(\mathrm{r}=.552, \mathrm{p}<0.01)$, "Digital abilities to complete academic work" ( $\mathrm{r}=.503$, $\mathrm{p}<0.01)$, "Digital identity management" $(\mathrm{r}=, 531, \mathrm{p}<0,01)$, and "Digital wellbeing” ( $\mathrm{r}=.587$, $\mathrm{p}<0.01)$. These are reported in column 2 of Table 5 .

Although, an additional number of correlations among the participants' competences dimensions (Table 5), can be identified, it is important to highlight that strong (r-value above 0.5) positive correlations are present for self-reported competences which concern "Digital wellbeing" with "ICT Proficiency with completing different tasks" $(\mathrm{r}=.601, \mathrm{p}<0.01)$, "ICT Productivity" $(\mathrm{r}=.552, \mathrm{p}<0.01)$, "Information Literacy skills" $(\mathrm{r}=.571, \mathrm{p}<0.01)$, "Digital research skills" $(\mathrm{r}=.594, \mathrm{p}<0.01)$, "Digital communication skills" $(\mathrm{r}=.693, \mathrm{p}<., 01)$, "Digital learning and development" $(\mathrm{r}=.595, \mathrm{p}<0.01)$, and "Digital abilities to complete academic work" $(\mathrm{r}=.595, \mathrm{p}<0.01)$.

\section{Qualitative responses}

Overall, $25 \%$ of the survey participants $(n=41)$ responded to one or more open-ended questions. Participant responses to the open-ended questions of the survey include interesting comments on the different ways in which students develop everyday life digital competences for e- 
democracy, e-government, e-health, e-leisure, and e-learning etc. Basic thematic analysis of the responses indicated three main conceptual categories relating to the ways in which participants developed their learning: a) via the use of digital tools and the support of other people, b) selftaught c) via learning taking place at school or work (or both). Indicative statements for "Everyday participation as a Digital Citizen on utilitarian and hedonic based activities" included the following:

- "They grew out of e-leisure activities on Twitter and Facebook, contacting like-minded people and having online spaces in which to meet, converse and organize" (learning experiences via people and tools).

- "Having worked in research and academia I was able to translate skills around finding, searching, interpreting and analysing online information to e-government sites and tasks" (learning experiences via previous work).

- "I grew up learning about computers and I've spent a good deal of time on the internet. I guess I have a lot of practice figuring things out for myself" (self-taught learning experiences).

- "Some K-12 courses (i.e., typing), but generally common sense and clicking around until I figure it out. I also utilize YouTube tutorial videos frequently" (learning experiences via school).

In relation to the open-ended questions for the competences dimension of "Digital learning and development" students' answers indicated that they manage their engagement and participation in digital learning environments, using a combination of methods, such as working collaboratively with other learners, adopting new ways of learning online and using digital tools where appropriate. These included both formal and informal approaches which are highlighted as follows:

- "Trial and error/practice, using help functions, asking other users or organisational help" (home informal \& formal work-based learning).

- "By formal and informal studying and routinely practicing the skills" (formal \& informal learning).

- "Through learning new skills during work and training at my work, as well as utilizing technology in my free time" (home informal \& formal work-based learning).

- "Over time, through classes and trial and error. Growing up in the digital age, the digital world is an essential tool" (home informal \& formal education-based learning).

Finally, interesting findings were also drawn from the participant responses to the open-ended question in relation to the competences dimension of the development of "ICT Proficiency with 
completing different tasks", including, again, comments about home, self-taught and collaborative experiences on the use of digital tools (i.e. Web browsers, search engines, services, software and devices):

- 'I don't really remember learning how to use any of these tools so again I would say I think I was self-taught. I probably sat down at a computer and just tried to figure things out" (self-taught).

- "As I learn best by doing something, I learned most of the tools above through trial and error. Periodically, a friend might mention a feature on a social media site or web browser that I had not heard of before and I will try it out and ask for assistance if I cannot figure it out. If I cannot do it on my own, I typically ask for help from my spouse" (informal learning via people, \& tools)

- "I became very familiar with university digital services when studying for my undergraduate degree. There was an introductory IT class is our first year, but most learning came from personal experience" (home informal \& formal education-based learning).

- "Software - mostly experience through my studies and work. Editing documents, maintaining spreadsheets and creating presentations have been central to both" (home informal \& formal work-based learning).

\section{Discussion}

\section{Digital Competences Development}

The survey results highlighted that students' self-assessments of digital competences were lacking in a number of areas which involved the development of a) information literacy skills that specifically addressed the aspect of referencing digital information sources and adhering to a referencing style, b) digital creation skills which addressed coding and designing apps, digital games, virtual environments, and interfaces c) digital research skills linked with tools analysing digital research data and d) digital identity management on the basis of analysing digital impact, footprint, and reputation using analytics or other digital tools.

Interestingly, none of the students perceived themselves as 'experts' in any of the digital competences areas but there were several reported 'advanced' digital competences which related mainly to ICT Proficiency with completing different tasks using digital tools, information literacy, and digital wellbeing. These three areas performed overall strongly in most of their components. 
In addition, it should be noted that "information literacy", "digital research skills" and "digital identity management" had different subcomponents that were ranked as 'basic' and 'advanced' within each category. For example, within the "information literacy" broad category, while the students felt competent in relation to finding and sharing information online, they required more help in referencing digital information sources and adhering to referencing styles. This is an interesting result, considering that the nature of the courses that these students studied, which involved the development of referencing skills and organising information, and preparing them with important skills as future information professionals. However, previous research has found that students in different subject areas encounter difficulties with referencing, which are related to the practical aspects of creating a reference (different styles, citing multiple authors, citing web content) (Brown et al., 2008; Switaj, 2015; Arce Espinoza and Monge Nájera, 2015), to understanding the concept of plagiarism and using references in academic writing, such as citing a source mentioned in another text (Brown et al., 2008; Neville, 2009).

Similarly, in the area of "digital identity management" students were well aware of the potential impact of what they communicated online on their digital reputation, but they struggled to analyse their digital impact, footprint, and reputation using analytics or other digital tools. In relation to "digital research skills", students perceived themselves to be advanced around organising and storing digital research data and following ethical, legal, and security guidelines when using research, but they struggled on the basis of analysing digital research data using simple tools. The findings of the above two digital competence categories "digital research skills" and "digital identity management", also indicate that students encountered difficulties in the aspect of developing practical skills and using tools for the purposes of 'analysis'. These findings indicate that particular focus may be required on the development of individual skillssets extracted from the broader composite areas of digital competences.

Finally, the area of "digital creation" also appears to require additional support, especially in the aspect of coding and designing apps, digital games, virtual environments, and interfaces. This is an important area of development for students, as future librarians working with apps and new technologies to deliver digital library services and digital information products. This is therefore an area for further development on the basis of both continuous professional development and curriculum focus.

\section{Everyday Life Digital Competences}

The results of this study indicate that the development of digital competencies of students is linked with their previous experiences in the everyday life digital environment. The higher the self-perceived digital competence levels of students were on the basis of dealing with everyday life digital tasks, the more likely they were to also develop high self-perceived competence in 
other areas which related to how they handled ICT tools, how they identified and evaluated digital information in different contexts, and how they researched, evaluated, shared, created, communicated, learned and innovated, by means of using digital information and tools. Interestingly, the students' responses also indicated a connection between what they had learned with reference to the everyday life environment and how they developed important digital abilities to complete tasks that were required of them within their academic learning context. These included tasks, such as participating in online learning opportunities, adopting new ways of learning online (e.g., online courses, e-tutorials, webinars), working collaboratively and supportively with other learners, using online technologies, using online tools to take notes, annotate, and collate learning materials, review, and revise learning, as well as receiving and responding to online feedback about their academic work, engaging and participating in online learning environments and sharing online knowledge and skills, helping other learners (e.g. mentoring others). In addition, everyday life digital competences, influenced students' self-perceptions of digital wellbeing competences, in other words how they dealt with the pressures of the online environment on the basis of handling information and technologies (i.e. whether they felt comfortable, in control, and safe when using digital technologies, whether they recognised that digital information and media can cause distraction, overload, and stress and knowing when to disconnect).

The Educause Horizon Report (Alexander et al., 2019), compiled by an expert panel of Higher Education leaders, provides an overview of emerging trends, challenges and important developments in educational technology from across the Higher Education landscape, describing an era of digital transformation and change. The current trends, among others, include the need to redesign learning spaces and drive the adoption of technology and advance "cultures of innovation". However, in order to achieve this change, the integration of digital learning innovations only would not suffice. There are a number of challenges that need to be overcome such as improving digital fluency:

"Digital fluency is the ability to leverage digital tools and platforms to communicate critically, design creatively, make informed decisions, and solve wicked problems while anticipating new ones. Merely maintaining the basic literacies by which students and instructors access and evaluate information is no longer sufficient to support the complex needs of a digitally mediated society" (Alexander et al., 2019; p.14).

In order to embrace digital fluency in Higher Education, an important condition relates to addressing digital gaps and inequities; these are broadened by the increasing digitisation and integration of technology within the modern academic learning environment but also within the everyday life sphere, where not everyone has an equal access to participate or fully engage with 
digital opportunities for learning, societal participation and personal development. As has been already indicated, LIS students' socio-demographic synthesis is quite diverse including individuals from different and international backgrounds, i.e. different income and social status, age groups, origins from under developed countries, cultures and religions etc. Indeed, digital inequality is a timely and valuable issue created on the basis of people's diverse demographic variables such as income, education, gender, age, ability status, native language, as well as other cultural, national or regional disparities (Alexander et al., 2019).

In relation to the Higher Education related context, the use of sophisticated digital platforms for course delivery, the shift to online marking and assessment and the use of interactive digital teaching and learning methods, signals a need to examine what may accelerate existing digital inequalities in students who have not had the same access to the digital environment or opportunities to develop digital competences as part of their earlier experiences of learning, work and everyday life. For instance, our survey results provide initial indications that prioruniversity experiences impacts students' reported competences, e.g. older and/or postgraduate students (23-38 years old/Millennials) report higher level of competences in terms of "everyday participation as a digital citizens on utilitarian based activities" (e-democracy, e-government, e-health) when compared to younger individuals; while the same is observed for "digital learning and development", “digital identity management", and "digital wellbeing”. Learning and teaching in Higher Education has changed significantly in the last few years with new models of eLearning provision which require not only fast Internet access but also the use of digital devices and the development of digital learning behaviours (e.g. via online fora, wiki activities, webinars and interactive online boards) (Alexander et al., 2019). The expectation is that students, upon entering their studies, will have already developed essential digital competences, which will enable them to not only handle online digital tools for learning but also use them in authentic and innovative ways, follow specific netiquette expectations and develop digital resilience. However, students are widely different in both their familiarity and use of digital tools and an "intentional differentiation and scaffolding" is required (Nicholson and Galguera, 2013). Further research on students' digital inequalities may identify additional challenges in the form of digital barriers in students' efforts to fully participate in emerging digital course designs.

\section{Demographic Differences}

As explained above, the results of the study presented a variation on the basis in which different students self-assessed their everyday life digital competences for utilitarian activities based on age demographics, level of study and year of study. Interestingly the older participants were the higher their ranked their skills in this area for e-democracy, e-government, e-health, 
suggesting that these competences develop together with life experiences. This was observed equally in relation to experiences related to studying (year and level of study), with more years of learning experience indicating higher level competences. On the other hand, the results for hedonic activities (e-leisure and e-learning) indicated a moderate association with the study level only. This is a result that requires more study and further research to be explained and further elaborated. However, the findings of this study suggest that everyday life digital competencies may develop over time and that we may have to explore the involvement of younger students in areas such as e-democracy, e-government and e-health with a view to assisting them develop higher competence levels in these areas.

Recent research by Gibson and Smith (2018), supporting this view, is one of a few focusing on the 'information journey' dimension of digital literacies considering their lifelong learning experiences with information, and comparing the similarities and differences between child and adult learners. The perception that there is a single generation of students who are 'digital natives' is a generalist assumption and has been repeatedly challenged by previous research in different domains in terms of failing to recognise other prevailing differences on the basis of complex demographics, as well as other characteristics which include students' study discipline, their gender and their education level as well as their parents' own education levels. There are a number of earlier studies, for example, that have found that disciplinary differences among students influence their digital use (Kemp and Jones, 2007; Macdonald et al., 2001; McDowell, 2002). This again, points to the significance of exploring digital competencies in the continuum of students' life-long learning experiences and in relation to their different backgrounds.

\section{Conclusions}

Students are considered to be digital competent when entering Higher Education studies, whether that is for undergraduate study or further learning. Current debates in this area do not offer a conclusive answer with many complex demographics and other factors playing a role in determining whether and when students master essential digital competencies. As Braveman (2016) has observed, "At most, universities digital literacy is either taken for granted or assumed to be at an adequate level, rather than being assessed, remediated, and amplified." Higher education has not fully embraced digital competences as a core, fundamental literacy which addresses both ICT and digital citizenship needs, at the heart of learning in the same way as other traditional literacies such as reading and writing. The increasing significance attached to the use of technology-based tools as a natural and expected aspect of education is now entering a phase, where it is logical to ask the question: 'Since students' digital competence 
development is not yet at the centre of educational strategy, has the prevalence of technology in academia already exacerbated the digital divide for some of them?'

Although many students arrive at university with at least some basic understanding or with some experience of having used technology and the Internet, it is still uncertain whether they have developed experience with issues that relate to the challenges of the digital society and online connectivity in an efficient, responsible and resilient manner. At the same time, there is still a prevailing confusion in Higher Education which relates to digital competences as being equivalent to ICT skills. As emerging models of teaching and learning are now starting to challenge traditional based paradigms with more emphasis on online teamwork, flipped classrooms, tailored learning and global connectivity, existing digital divides may be further accelerated. This requires revisiting the development of digital competences from the perspective of both students and academic staff that are expected to drive this new direction. According to Bulfin and Koutsogiannis (2012) “... digital literacies are best understood as multiply situated across home and school domains, or in other words, they are multiply placed practices" (p.331). This study demonstrated that understanding how people interact with the digital environment within their everyday lives can provide valuable insights for 'formal' education provision.

\section{References}

Alexander, B., Ashford-Rowe, K., Barajas-Murph, N., Dobbin, G., Knott, J., McCormack, M. ... and Weber, N. (2019), EDUCAUSE Horizon Report 2019: Higher Education Edition, EDUCAUSE, Louisville, CO.

Arce Espinoza, L. and Monge Nájera, J. (2015), "How to correct teaching methods that favour plagiarism: recommendations from teachers and students in a Spanish language distance education university", Assessment \& Evaluation in Higher Education, Vol. 40 No. 8, pp. 1070-1078.

Balog, K.P. and Siber, L. (2014), "Students of law and e-Democracy", in Kurbanoglu, S., Špiranec, S., Grassian, E., Mizrachi, D., \& Catts, R. (Eds.), Proceedings of the Second European Conference, ECIL 2014, "Information Literacy: Lifelong Learning and Digital Citizenship in the 21st Century", Dubrovnik, Croatia, pp. 663-672.

Bawden, D. (2001), "Information and digital Literacies: A review of concepts", Journal of Documentation, Vol.57 No.2, pp. 218-259. 
Bawden, D. (2008), "Origins and Concepts of Digital Literacy”, in Lankshear, C. and Knobel, M (Eds), Digital literacies: Concepts, policies and practices, Peter Lang, New York, NY, pp. 17-32.

Bawden, D. and Robinson, L. (2002), "Promoting literacy in a digital age: approaches to training for information literacy", Learned Publishing, Vol. 15 No. 4, pp. 297-301.

Bennett, S., Maton, K. and Kervin, L. (2008), “The 'digital natives' debate: A critical review of the evidence", British journal of educational technology, Vol. 39 No. 5, pp. 775786.

Blanch-Hartigan, D. (2011), "Medical students' self-assessment of performance: results from three meta-analyses", Patient education and counseling, Vol. 84 No. 1, pp. 3-9.

Blossfeld, H.P. and von Maurice, J. (2019), "Education as a lifelong process", Blossfeld, H.-P., \& Robbach, H.-G. (Eds.), Education as a Lifelong Process, Springer, Wiesbaden, pp. 17-33.

Braverman, B. (2016), "The digital divide: How income inequality is affecting literacy instruction, and what all educators can do to help close the gap", Literacy Today, Vol. 33 No. 4, pp. 16-20.

Brown, C.A., Dickson, R., Humphreys, A.L., McQuillan, V. and Smears, E. (2008), "Promoting academic writing/referencing skills: Outcome of an undergraduate e-learning pilot project", British journal of educational technology, Vol. 39 No. 1, pp. 140-156.

Brown, G.T., Andrade, H.L. and Chen, F. (2015), "Accuracy in student self-assessment: directions and cautions for research. Assessment in Education: Principles", Policy \& Practice, Vol. 22 No. 4, pp. 444-457.

Bulfin, S. and Koutsogiannis, D. (2012), "New literacies as multiply placed practices: expanding perspectives on young people's literacies across home and school", Language and Education, Vol. 26 No. 4, pp. 331-346.

Callinan, J.E. (2005), "Information-seeking behaviour of undergraduate biology students", Library Review, Vol. 54 No. 2, pp. 86-99.

Carretero, S., Vuorikari, R. and Punie, Y. (2017), DigComp 2.1: The digital competence framework for citizens with eight proficiency levels and examples of use, Publications Office of the European Union, Luxembourg. 
Catalano, A. (2013), "Patterns of graduate students' information seeking behavior: a metasynthesis of the literature", Journal of Documentation, Vol. 69 No. 2, pp. 243-274.

Ciardo, A., Möltner, A., Rüttermann, S. and Gerhardt-Szép, S. (2019), "Students' selfassessment of competencies in the phantom course of operative dentistry", European Journal of Dental Education, Vol. 23 No. 2, pp. 204-211.

Comrey, A.L. and Lee, H.B. (1992), A first course in factor analysis (2nd ed.), Lawrence Erlbaum Associates, Hillsdale, NJ, USA.

Crown Commercial Service (2016), "Digital Training and Support", available at: https://www.contractsfinder.service.gov.uk/Notice/c887d39a-626d-43a4-982ae39bf5de6048?p=@j,jNT08=UFQxU1RRPT0=N (accessed 6 March 2020).

Cullen, R., Clark, M. and Esson, R. (2011), "Evidence-based information-seeking skills of junior doctors entering the workforce: an evaluation of the impact of information literacy training during pre-clinical years", Health Information \& Libraries Journal, Vol. 28 No. 2, pp. 119-129.

Dimock, M. (2019), "Defining generations: Where Millennials end and Generation Z begins", Pew Research Center, available at: https://www.pewresearch.org/facttank/2019/01/17/where-millennials-end-and-generation-z-begins/ (accessed 22 May 2020).

Drigas, A., Bravou, V., Demertzi, E. and Papagerasimou, Y. (2019), "Media Literacy in the Digitalised Era: supporting teachers through a whole-school approach", available at: http://meldeproject.eu/wpcontent/uploads/2019/07/MeLDE_IO1_GREEK_NATIONAL_REPORT.pdf (accessed 6 March 2020).

Du, J.T. and Evans, N. (2011) "Academic users' information searching on research topics: Characteristics of research tasks and search strategies", The Journal of Academic Librarianship, Vol. 37 No. 4, pp. 299-306.

Elder, G.H., Johnson, M.K. and Crosnoe, R. (2003), "The emergence and development of life course theory", Mortimer, J.T., \& Shanahan, M.J. (Eds.), Handbook of the life course, Springer, Boston, MA, pp. 3-19.

European Commission (2019), "The Digital Economy and Society Index (DESI)”, available at: https://ec.europa.eu/digital-single-market/en/desi (accessed 6 March 2020). 
European Commission (2020), "ET2020 Working Group on Digital Education: Learning, Teaching and Assessment", available at: https://ec.europa.eu/transparency/regexpert/index.cfm?do=groupDetail.groupDetail\& groupID=3407 (accessed 6 March 2020).

Fulton, C. and McGuinness, C. (2016), Digital detectives: Solving information dilemmas in an online world, Chandos Publishing, Kidlington, UK - Cambridge, MA, USA.

Fulton, C., Bustillo, M., McGuinness, C., Guerin, S. and Browne, A. (2020), "Designing a Digital Research Accelerator Programme for the Social Sciences at UCD: Preliminary results of a faculty-library collaboration", New Review of Academic Librarianship, available at: https://doi.org/10.1080/13614533.2020.1765818 (accessed 22 May 2020).

Gazi, Z.A. (2016), "Internalization of digital citizenship for the future of all levels of education”, Education and Science, Vol. 41 No. 186, pp. 137-148.

Gibson, P.F. and Smith, S. (2018), "Digital literacies: preparing pupils and students for their information journey in the twenty-first century", Information and Learning Science, Vol. 119 No. 12, pp. 733-742.

Gilster, P. (1997), Digital literacy, Wiley Computer Publications, New York, NY.

Gkorezis, P., Kostagiolas, P. and Niakas, D. (2017), "Linking exploration to academic performance: The role of information seeking and academic self-efficacy", Library Management, Vol. 38 No. 8/9, pp. 404-414.

Good Things Foundation (2018). "The economic impact of Digital Inclusion in the UK: A report for Good Things Foundation", available at: https://www.goodthingsfoundation.org/research-publications/economic-impactdigital-inclusion-uk (accessed 6 March 2020).

Government Office for Science (2017), "Future of Skills and lifelong Learning", GOV.UK, available at: https://www.gov.uk/government/publications/future-of-skills-andlifelong-learning (accessed 6 March 2020).

Greek Ministry of Education (2010-5), "The Digital School project", available at https://dschool.edu.gr/p61cti/ (accessed 6 March 2020).

Gross, M. and Latham, D. (2012), "What's skill got to do with it?: Information literacy skills and self-views of ability among first-year college students", Journal of the American Society for Information Science and Technology, Vol. 63 No. 3, pp. 574-583. 
Head, A.J. and Eisenberg, M.B. (2009), "Finding Context: What Today's College Students Say about Conducting Research in the Digital Age”, Project Information Literacy Progress Report, available at: https://files.eric.ed.gov/fulltext/ED535161.pdf (accessed 22 May 2020).

Helms-Park, R., Radia, P. and Stapleton, P. (2007), “A preliminary assessment of Google Scholar as a source of EAP students' research materials", The Internet and Higher Education, Vol. 10 No. 1, pp. 65-76.

Holbrook, M.B. and Hirschman, E.C. (1982), "The experiential aspects of consumption: Consumer fantasies, feelings, and fun", Journal of consumer research, Vol. 9 No. 2 , pp. 132-140.

Hollandsworth, R., Dowdy, L. and Donovan, J. (2011), "Digital citizenship in K-12: It takes a village", TechTrends, Vol. 55 No. 4, pp. 37-47.

Huang, Y.M. (2020), “Students' Continuance Intention Toward Programming Games: Hedonic and Utilitarian Aspects", International Journal of Human-Computer Interaction, Vol. 36 No. 4, pp. 393-402.

Iansiti, M. and Richards, G. (2020), "Coronavirus Is Widening the Corporate Digital Divide", Harvard Business Review, available at: https:/hbr.org/2020/03/coronavirus-iswidening-the-corporate-digital-divide?autocomplete=true (accessed 22 May 2020).

Ilomäki, L., Kantosalo, A. and Lakkala, M. (2011), “What is digital competence?”, in Linked portal, European Schoolnet (EUN), Brussels, pp. 1-12.

International Federation of Library Associations and Institutions (IFLA) (2017), "IFLA Statement on Digital Literacy", available at: https://www.ifla.org/publications/node/11586 (accessed 6 March 2020).

Joint Information Systems Committee (JISC) (2012), "Developing Digital Literacies programme", available at: https:/www.webarchive.org.uk/wayback/archive/20140613220103/http://www.jisc.a c.uk/whatwedo/programmes/elearning/developingdigitalliteracies/developingdigitallit eraciesprog.aspx (accessed 6 March 2020).

Joint Information Systems Committee (JISC) (2014), "Digital literacies: Joined-up approaches to digital literacy development to support student achievement and employability", available at: https://www.jisc.ac.uk/rd/projects/digital-literacies (accessed 6 March 2020). 
Joint Information Systems Committee (JISC) (2015a), "Integrating digital literacy with enquiry-based learning", available at: https://digitalstudent.jiscinvolve.org/wp/files/2015/01/DS23-Integrating-digitalliteracy-with-enquiry-based-learning.pdf (accessed 22 May 2020).

Joint Information Systems Committee (JISC) (2015b), "Frameworks mapped to the six elements", available at: https://digitalcapability.jiscinvolve.org/wp/files/2015/06/3.Frameworks-mapped-to-6-elements.pdf (accessed 6 March 2020).

Joint Information Systems Committee (JISC) (2017), "Case studies: journeys towards digital capability", available at: https://www.jisc.ac.uk/guides/developing-organisationalapproaches-to-digital-capability/case-studies (accessed 22 May 2020).

Joint Information Systems Committee (JISC) (2019), "Discovery Tool", available at: https://digitalcapability.jisc.ac.uk/our-service/discovery-tool// (accessed 6 March 2020).

Kara, N. (2018), 'Understanding university students' thoughts and practices about digital citizenship: A mixed methods study", Journal of Educational Technology \& Society, Vol. 21 No. 1, pp. 172-185.

Kemp, B. and Jones, C. (2007), “Academic use of digital resources: Disciplinary differences and the issue of progression revisited", Journal of Educational Technology \& Society, Vol. 10 No. 1, pp. 52-60.

Khan, U., Dhar, R. and Wertenbroch, K. (2005), “A behavioral decision theory perspective on hedonic and utilitarian choice", in Ratneshwar, S. and Mick, D.G. (Eds), Inside Consumption: Frontiers of Research on Consumer Motives, Goals, and Desires, Routledge, London, UK, pp. 166-187.

Knight, C. and Pryke, S. (2012), "Wikipedia and the University, a case study", Teaching in Higher Education, Vol. 17 No. 6, pp. 649-659.

Kruger, J. and Dunning, D. (1999), "Unskilled and unaware of it: How difficulties in recognizing one's own incompetence lead to inflated self-assessments", Journal of Personality and Social Psychology, Vol. 77 No. 6, pp. 1121-1134.

Laurillard, D., Derrick, J. and Doel, M. (2016), "Building digital skills in the FE sector: Future of skills and lifelong learning", Government Office for Science, London, UK. 
Liu, Z. (2006), "Print vs. electronic resources: a study of user perceptions, preferences, and use", Information Processing \& Management, Vol. 42 No. 2, pp. 583-592.

Loomis, D.K. and Paterson, S. (2018), "A comparison of data collection methods: Mail versus online surveys", Journal of Leisure Research, Vol. 49, No. 2, pp. 133-149.

MacDonald, J., Heap, N. and Mason, R. (2001), “"Have I learnt it?" Evaluating skills for resource-based study using electronic resources", British Journal of Educational Technology, Vol. 32 No. 4, pp. 419-433.

Margaryan, A., Littlejohn, A. and Vojt, G. (2011), “Are digital natives a myth or reality? University students' use of digital technologies", Computers and Education: An International Journal, Vol. 56 No. 2, pp. 429-440.

Martzoukou, K. (2008), "Students' attitudes towards web search engines: increasing appreciation of sophisticated search strategies", Libri, Vol. 58 No. 3, pp. 182-201.

Martzoukou, K. and Sayyad, E. (2017), “Towards an everyday life information literacy mindset: A review of literature.” Journal of Documentation, Vol. 7 No. 4, pp. 634-665.

McDowell, L. (2002), "Electronic information resources in undergraduate education: an exploratory study of opportunities for student learning and independence", British Journal of Educational Technology, Vol. 33 No. 3, pp. 255-266.

McGrew, S., Breakstone, J., Ortega, T., Smith, M. and Wineburg, S. (2018), "Can students evaluate online sources? Learning from assessments of civic online reasoning", Theory \& Research in Social Education, Vol. 46 No. 2, pp. 165-193.

McGuinness, C. and Fulton, C. (2019), "Digital literacy in higher education: a case study of student engagement with e-tutorials using blended learning", Journal of Information Technology Education: Innovations in Practice, Vol. 18, pp. 1-28.

Megalou, E. and Kaklamanis, C. (2014), "Photodentro LOR, the Greek national learning object repository", in 8th International Technology, Education and Development Conference (INTED2014) proceedings in Valencia, Spain, 2014, IATED, Valencia, pp. 309-319.

Ministry of Digital Policy, Telecommunications and Media (2016), "National Digital Policy 2016-21", available at: https://mindigital.gr/old/images/GENIKOI/RALIS/PDF/Digital_Strategy_2016_2021 .pdf (accessed 6 March 2020). 
Mittermeyer, D. (2005), "Incoming first year undergraduate students: How information literate are they?", Education for information, Vol. 23 No. 4, pp. 203-232.

Moore, R., Vitale, D. and Stawinoga, N. (2018), “The Digital Divide and Educational Equity: A Look at Students with Very Limited Access to Electronic Devices at Home”, Insights in Education and Work, ACT, Inc., available at: https://files.eric.ed.gov/fulltext/ED593163.pdf (accessed 22 May 2020).

Morgan, S. (2019), "Focus on Graduate Skills", The Quality Assurance Agency for Higher Education, available at: https://www.qaa.ac.uk/docs/qaas/focus-on/employers\%27and-graduates\%27-views-of-graduate-skills-report-2019-0822.pdf?sfvrsn=8906c681_8 (accessed 22 May 2020).

National Forum for the enhancement of Teaching and Learning in Higher Education (T\&L) (2019), "Irish National Digital Experience Survey (INDEx)", available at: https://www.teachingandlearning.ie/index// (accessed 6 March 2020).

National Literacy Trust (2018), "Fake news and Critical Literacy: The final report of the Commission on Fake News and the Teaching of Critical Literacy in Schools", available at:

https://cdn.literacytrust.org.uk/media/documents/Fake news and critical_literacy_final_report.pdf (accessed 22 May 2020).

Neville, C. (2009), "Student Perceptions of Referencing. Referencing \& Writing Symposium", available at: http://learnhigher.ac.uk/resources/files/Referencing/Research\%20report.doc (accessed 6 March 2020).

Ng, W. (2012), “Can We Teach Digital Natives Digital Literacy?”, Computers \& Education, Vol. 59 No. 3, pp. 1065-1078.

Nicholson, J. and Galguera, T. (2013), "Integrating New Literacies in Higher Education: A Self-Study of the Use of Twitter in an Education Course", Teacher Education Quarterly, Vol. 40 No. 3, pp. 7-26.

Ofcom (2017), "Children and Parents: Media Use and Attitudes Report", available at: https://www.ofcom.org.uk/_data/assets/pdf file/0020/108182/children-parentsmedia-use-attitudes-2017.pdf (accessed 6 March 2020). 
Ofcom (2020), "Children and parents: Media use and attitudes report 2019", available at: https://www.ofcom.org.uk/ data/assets/pdf file/0023/190616/children-media-useattitudes-2019-report.pdf (accessed 22 May 2020).

Oxford Brookes University, "Digital Capabilities for Students", available at: https://www.brookes.ac.uk/digital-capabilities-for-students/ (accessed 22 May 2020).

Picton, I. and Teravainen, A. (2017), Fake news and critical literacy: An evidence review, The National Literacy Trust, London, UK.

Poropat, A.E. (2009), "A meta-analysis of the five-factor model of personality and academic performance", Psychological Bulletin, Vol. 135 No. 2, pp. 322-338.

Prebensen, N.K. and Rosengren, S. (2016), "Experience value as a function of hedonic and utilitarian dominant services", International Journal of Contemporary Hospitality Management, Vol. 28 No. 1, pp. 113-135.

Prensky, M. (2001), "Digital natives, digital immigrants," On the Horizon, Vol. 9 No. 5, pp. $1-6$.

Queen's University Belfast, "Transition Skills Programme", available at: https://www.qub.ac.uk/elearning/transition-skills (accessed 22 May 2020).

Ribble, M.S. and Bailey, G.D. (2004), "Digital citizenship focus questions for implementation", Learning \& Leading with Technology, Vol. 32 No. 2, pp. 12-15.

Rowlands, I., Nicholas, D., Williams, P., Huntington, P., Fieldhouse, M., Gunter, B., ... and Tenopir, C. (2008), "The Google generation: The information behaviour of the researcher of the future". Aslib Proceedings: New Information Perspectives, Vol. 60, No. 4, p. 290-310.

Spante, M., Hashemi, S.S., Lundin, M. and Algers, A. (2018), "Digital competence and digital literacy in higher education research: Systematic review of concept use", Cogent Education, Vol. 5 No. 1, 1519143.

Switaj, E. (2015), "Web writing and citation: The authority of communities", in Dougherty, J. and O'Donnell, T.L. (Eds), Web writing: Why and how for liberal arts teaching and learning, University of Michigan Press, Michigan, MI, p. 223-232.

Tabachnick, B.G. and Fidell, L.S. (2007), Using multivariate statistics (5th ed.), Pearson Allyn \& Bacon, Upper Saddle River, NJ, USA. 
The Open University (2016), "Digital and Information Literacy Framework" available at: http://www.open.ac.uk/libraryservices/subsites/dilframework/ (accessed 6 March 2020).

Thorne, S.L. (2013), "Digital literacies", in Hawkins, M. (Ed.), Framing Languages and Literacies: Socially Situated Views and Perspectives, Routledge, New York, NY, pp. 202-228.

Torney-Purta, J., Cabrera, J.C., Roohr, K.C., Liu, O.L. and Rios, J.A. (2015), “Assessing civic competency and engagement in higher education: Research background, frameworks, and directions for next-generation assessment", ETS Research Report Series, Vol. 2015 No. 2, pp. 1-48.

UK Department for Business Innovation \& Skills and Department for Culture Media \& Sport (2016), "Digital Skills for the UK economy: A report by ECORYS UK", available at: https://assets.publishing.service.gov.uk/government/uploads/system/uploads/attachme nt data/file/492889/DCMSDigitalSkillsReportJan2016.pdf (accessed 6 March 2020).

UK Department for Digital, Culture, Media \& Sport (2017), “UK Digital Strategy 2017”, available at: https://www.gov.uk/government/publications/uk-digital-strategy/ukdigital-strategy (accessed 6 March 2020).

UK Department for Digital, Culture, Media \& Sport and The Rt Hon Karen Bradley MP (2018), "Internet Safety Strategy green paper", available at: https://www.gov.uk/government/consultations/internet-safety-strategy-green-paper (accessed 6 March 2020).

UK Department for Education (2019), "Essential digital skills framework”, GOV.UK, available at: https://www.gov.uk/government/publications/essential-digital-skills-framework (accessed 6 March 2020).

UK Higher Education Academy (2017), "Digital literacies", AdvanceHE, available at: https://www.heacademy.ac.uk/knowledge-hub/digital-literacies (accessed 6 March 2020).

Ulster University (2017), "Library Digital and Information Literacy Strategy 2017 - 2021", available at: https://www.ulster.ac.uk/ data/assets/pdf file/0004/390937/Digitaland-Information-Literacy-Strategy.pdf (accessed 6 March 2020). 
University of "My Digital Literacy", available at: https://www.bolton.ac.uk/leaponline/My-Digital-Literacy/Home.aspx; （accessed 22 May 2020).

University of "iTest", Exeter, available at: http://as.exeter.ac.uk/media/universityofexeter/academicservices/educationenhancem ent/collaborate/iTest_v2.5.pdf (accessed 22 May 2020).

University of Sheffield, "Pre-entry Information and Digital Literacy Tutorials", available at: https://www.sheffield.ac.uk/library/idlt/preentry (accessed 22 May 2020).

White, D.S. and Le Cornu, A. (2011), "Visitors and residents: a new typology for online engagement", First Monday, Vol. 16 No. 9, available at: https://doi.org/10.5210/fm.v16i9.3171 (accessed 6 March 2020).

Wineburg, S., McGrew, S., Breakstone, J. and Ortega, T. (2016), "Evaluating information: The cornerstone of civic online reasoning", Stanford History Education Group, available at; https://purl.stanford.edu/fv751yt5934 (accessed 22 May 2020).

\section{Appendices}

\section{Appendix I - Descriptive Statistics}

\begin{tabular}{|c|c|c|c|c|c|c|c|c|}
\hline \multicolumn{2}{|c|}{$\begin{array}{l}\text { Table 1: Descriptive statistics for Q.3 "Please } \\
\text { rank your ICT Proficiency with completing } \\
\text { different tasks using the following digital tools": }\end{array}$} & \multicolumn{7}{|c|}{$1=$ Novice, $2=$ Basic, $3=$ Intermediate, $4=$ Advanced, $5=$ Expert } \\
\hline & & 1 & 2 & 3 & 4 & 5 & Median & Mode \\
\hline 1.1 & Technological devices (valid $\mathrm{N}=164)^{\sigma}$ & $4(2,4 \%)$ & $8(4,9 \%)$ & $36(22 \%)$ & $79(48,2 \%)$ & $37(22,6 \%)$ & 4,00 & 4 \\
\hline 1.2 & Software (valid $\mathrm{N}=163)^{\mu, \lambda}$ & $11(6,7 \%)$ & $23(14,1 \%)$ & $60(36,8 \%)$ & $51(31,3 \%)$ & $18(11 \%)$ & 3,00 & 3 \\
\hline 1.3 & Web browsers (valid $\mathrm{N}=163)^{\sigma}$ & $4(2,5 \%)$ & $7(4,3 \%)$ & $\begin{array}{c}38 \\
(23,3 \%)\end{array}$ & $74(45,4 \%)$ & $\begin{array}{c}40 \\
(24,5 \%)\end{array}$ & 4,00 & 4 \\
\hline 1.4 & Search engines (valid $\mathrm{N}=163$ ) & $2(1,2 \%)$ & $8(4,9 \%)$ & $36(22,1 \%)$ & $\begin{array}{c}74 \\
(45,4 \%)\end{array}$ & $43(26,4 \%)$ & 4,00 & 4 \\
\hline 1.5 & $\begin{array}{l}\text { University digital administrative services } \\
(\text { valid } \mathrm{N}=164)^{v}\end{array}$ & $4(2,4 \%)$ & $16(9,8 \%)$ & $41(25 \%)$ & $70(42,7 \%)$ & $33(20,1 \%)$ & 4,00 & 4 \\
\hline 1.6 & $\begin{array}{l}\text { University learning management systems } \\
\text { (valid } \mathrm{N}=162)^{\alpha, \gamma, \mu, \lambda, v}\end{array}$ & $2(1,2 \%)$ & $16(9,9 \%)$ & $44(27,2 \%)$ & $59(36,4 \%)$ & $41(25,3 \%)$ & 4,00 & 4 \\
\hline 1.7 & Personal digital services (valid $\mathrm{N}=164$ ) & $4(2,4 \%)$ & $9(5,5 \%)$ & $37(22,6 \%)$ & $73(44,5 \%)$ & $41(25 \%)$ & 4,00 & 4 \\
\hline
\end{tabular}




\begin{tabular}{|c|c|c|c|c|c|c|c|c|c|c|}
\hline \multicolumn{2}{|c|}{$\begin{array}{l}\text { Table 2: Descriptive statistics for Q.4 } \\
\text { "Please rank your ICT Productivity in } \\
\text { relation to the areas listed below": }\end{array}$} & \multicolumn{9}{|c|}{$\begin{array}{l}\text { Competences Level Scale } \\
I=\text { Novice, } 2=\text { Basic, } 3=\text { Intermediate, } 4=\text { Advanced, } 5=\text { Expert }\end{array}$} \\
\hline & & 1 & 2 & 3 & 4 & 5 & Min. & Max. & Median & Mode \\
\hline 2.1 & $\begin{array}{l}\text { Organising, managing, storing, and } \\
\text { sharing digital files for your learning } \\
\text { through Internet spaces and/or your } \\
\text { university's online systems (valid } \\
\mathrm{N}=164)^{\mu, \lambda}\end{array}$ & $\begin{array}{c}10 \\
(6,1 \%)\end{array}$ & $\begin{array}{c}20 \\
(12,2 \%)\end{array}$ & $\begin{array}{c}62 \\
(37,8 \%)\end{array}$ & $\begin{array}{c}54 \\
(32,9 \%)\end{array}$ & $\begin{array}{c}18 \\
(11 \%)\end{array}$ & 1 & 5 & 3,00 & 3 \\
\hline 2.2 & $\begin{array}{l}\text { Selecting software and apps matched } \\
\text { to tasks (valid } \mathrm{N}=164)^{\sigma, \alpha, \gamma, \mu, \lambda}\end{array}$ & $\begin{array}{c}9 \\
(5,5 \%)\end{array}$ & $\begin{array}{c}37 \\
(22,6 \%)\end{array}$ & $\begin{array}{c}75 \\
(45,7 \%)\end{array}$ & $\begin{array}{c}39 \\
(23,8 \%)\end{array}$ & $\begin{array}{c}4 \\
(2,4 \%)\end{array}$ & 1 & 5 & 3,00 & 3 \\
\hline 2.3 & $\begin{array}{l}\text { Using tools, such as calendars, task } \\
\text { lists, project and time management } \\
\text { apps, to make learning more efficient } \\
\text { (valid } \mathrm{N}=163 \text { ) }\end{array}$ & $\begin{array}{c}15 \\
(9,2 \%)\end{array}$ & $\begin{array}{c}41 \\
(25,2 \%)\end{array}$ & $\begin{array}{c}55 \\
(33,7 \%)\end{array}$ & $\begin{array}{c}41 \\
(25,2 \%)\end{array}$ & $\begin{array}{c}11 \\
(6,7 \%)\end{array}$ & 1 & 5 & 3,00 & 3 \\
\hline & $\begin{array}{l}\text { Mann-Whitney U-test and Kruskal-Wall } \\
05 \text { current level of study). }\end{array}$ & 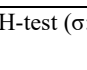 & 005 & $: p<0,05$ & 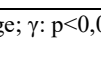 & 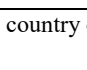 & . & 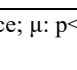 & $\mathrm{mar}$ & tatus; \\
\hline
\end{tabular}

\begin{tabular}{|c|c|c|c|c|c|c|c|c|c|c|}
\hline \multicolumn{2}{|c|}{$\begin{array}{l}\text { Table 3: Descriptive statistics for Q.5 } \\
\text { "To what level of identification of each } \\
\text { type of information in the following } \\
\text { contexts": }\end{array}$} & \multicolumn{9}{|c|}{$\begin{array}{l}\text { Competences Level Scale } \\
\end{array}$} \\
\hline & & 1 & 2 & 3 & 4 & 5 & Min. & Max. & Median & Mode \\
\hline 3.1 & $\begin{array}{l}\text { Scholarly literature (valid } \\
\mathrm{N}=163)^{\alpha, \gamma, \mu, \lambda}\end{array}$ & $\begin{array}{c}18 \\
(11 \%)\end{array}$ & $\begin{array}{c}42 \\
(25,8 \%)\end{array}$ & $\begin{array}{c}49 \\
(30,1 \%)\end{array}$ & $\begin{array}{c}43 \\
(26,4 \%)\end{array}$ & $\begin{array}{c}11 \\
(6,7 \%)\end{array}$ & 1 & 5 & 3,00 & 3 \\
\hline 3.2 & $\begin{array}{l}\text { Professional literature (valid } \\
\mathrm{N}=162)^{\alpha, \gamma, \mu, \lambda, v}\end{array}$ & $\begin{array}{c}28 \\
(17,3 \%)\end{array}$ & $\begin{array}{c}38 \\
(23,5 \%)\end{array}$ & $\begin{array}{c}54 \\
(33,3 \%)\end{array}$ & $\begin{array}{c}35 \\
(21,6 \%)\end{array}$ & $\begin{array}{c}7 \\
(4,3 \%)\end{array}$ & 1 & 5 & 3,00 & 3 \\
\hline 3.3 & $\begin{array}{l}\text { Popular information (valid } \\
\mathrm{N}=162)^{\alpha, \gamma, \mu, \lambda}\end{array}$ & $\begin{array}{c}12 \\
(7,4 \%)\end{array}$ & $\begin{array}{c}30 \\
(18,5 \%)\end{array}$ & $\begin{array}{c}44 \\
(27,2 \%)\end{array}$ & $\begin{array}{c}64 \\
(39,5 \%)\end{array}$ & $\begin{array}{c}12 \\
(7,4 \%)\end{array}$ & 1 & 5 & 3,00 & 4 \\
\hline & $\begin{array}{l}\text { Mann-Whitney U-test and Kruskal- } \\
\text { level of study; } v \text { : } p<0,05 \text { year of st }\end{array}$ & H-test & 0,05 age & $\mathrm{p}<0,05$ & ntry of & dence. & $<0,05$ & arital s & $\mathrm{s} ; \lambda: \mathrm{p}<$ & \\
\hline
\end{tabular}

\begin{tabular}{|c|c|c|c|c|c|c|c|c|c|c|}
\hline \multicolumn{2}{|c|}{$\begin{array}{l}\text { Table 4: Descriptive statistics for Q.6 } \\
\text { "Please rank your Information Literacy } \\
\text { skills in relation to the areas listed below": }\end{array}$} & \multicolumn{9}{|c|}{ Competences Level Scale } \\
\hline & & 1 & 2 & 3 & 4 & 5 & Min. & Max. & Median & Mode \\
\hline 4.1 & $\begin{array}{l}\text { Finding digital information relevant } \\
\text { to your academic studies, using } \\
\text { informal Web sources (valid } \\
\mathrm{N}=163)^{\alpha, \gamma, \lambda}\end{array}$ & $\begin{array}{c}9 \\
(5,5 \%)\end{array}$ & $\begin{array}{c}28 \\
(17,2 \%)\end{array}$ & $\begin{array}{c}53 \\
(32,5 \%)\end{array}$ & $\begin{array}{c}57 \\
(35 \%)\end{array}$ & $\begin{array}{c}16 \\
(9,8 \%)\end{array}$ & 1 & 5 & 3,00 & 4 \\
\hline 4.2 & $\begin{array}{l}\text { Finding digital information relevant } \\
\text { to your academic studies, using } \\
\text { scholarly sources (valid } \mathrm{N}=163)^{\alpha, \gamma, \lambda}\end{array}$ & $\begin{array}{c}4 \\
(2,5 \%)\end{array}$ & $\begin{array}{c}34 \\
(20,9 \%)\end{array}$ & $\begin{array}{c}49 \\
(30,1 \%)\end{array}$ & $\begin{array}{c}63 \\
(38,7 \%)\end{array}$ & $\begin{array}{c}13 \\
(8 \%)\end{array}$ & 1 & 5 & 3,00 & 4 \\
\hline 4.3 & $\begin{array}{l}\text { Using online collection tools for } \\
\text { gathering digital information together } \\
\text { in new ways (valid } \mathrm{N}=162 \text { ) }\end{array}$ & $\begin{array}{c}34 \\
(21 \%)\end{array}$ & $\begin{array}{c}47 \\
(29 \%)\end{array}$ & $\begin{array}{c}50 \\
(30,9 \%)\end{array}$ & $\begin{array}{c}22 \\
(13,6 \%)\end{array}$ & $\begin{array}{c}9 \\
(5,6 \%)\end{array}$ & 1 & 5 & 3,00 & 3 \\
\hline
\end{tabular}




\begin{tabular}{|c|c|c|c|c|c|c|c|c|c|c|}
\hline 4.4 & $\begin{array}{l}\text { Evaluating whether digital } \\
\text { information is trustworthy and } \\
\text { relevant (valid } \mathrm{N}=162)^{\alpha, \gamma, \mu, \lambda}\end{array}$ & $\begin{array}{c}6 \\
(3,7 \%)\end{array}$ & $\begin{array}{c}35 \\
(21,6 \%)\end{array}$ & $\begin{array}{c}61 \\
(37,7 \%)\end{array}$ & $\begin{array}{c}53 \\
(32,7 \%)\end{array}$ & $\begin{array}{c}7 \\
(4,3 \%)\end{array}$ & 1 & 5 & 3,00 & 3 \\
\hline 4.5 & $\begin{array}{l}\text { Organising the digital information } \\
\text { you find for your learning through } \\
\text { folders, bookmarks, reference } \\
\text { management software, and tagging } \\
(\text { valid } \mathrm{N}=162)^{\alpha, \gamma, \lambda}\end{array}$ & $\begin{array}{c}21 \\
(13 \%)\end{array}$ & $\begin{array}{c}43 \\
(26,5 \%)\end{array}$ & $\begin{array}{c}45 \\
(27,8 \%)\end{array}$ & $\begin{array}{c}41 \\
(25,3 \%)\end{array}$ & $\begin{array}{c}12 \\
(7,4 \%)\end{array}$ & 1 & 5 & 3,00 & 3 \\
\hline 4.6 & $\begin{array}{l}\text { Referencing digital information } \\
\text { sources, adhering to a referencing } \\
\text { style (valid } \mathrm{N}=162)^{\alpha, \gamma, \mu, \lambda, v}\end{array}$ & $\begin{array}{c}30 \\
(18,5 \%)\end{array}$ & $\begin{array}{c}45 \\
(27,8 \%)\end{array}$ & $\begin{array}{c}37 \\
(22,8 \%)\end{array}$ & $\begin{array}{c}40 \\
(24,7 \%)\end{array}$ & $\begin{array}{c}10 \\
(6,2 \%)\end{array}$ & 1 & 5 & 3,00 & 2 \\
\hline 4.7 & $\begin{array}{l}\text { Understanding how to share } \\
\text { information publicly online, } \\
\text { respecting and acknowledging the } \\
\text { work of others (valid } \mathrm{N}=158)^{\alpha, \gamma, \lambda}\end{array}$ & $\begin{array}{c}26 \\
(16,5 \%)\end{array}$ & $\begin{array}{c}33 \\
(20,9 \%)\end{array}$ & $\begin{array}{c}38 \\
(24,1 \%)\end{array}$ & $\begin{array}{c}48 \\
(30,4 \%)\end{array}$ & $\begin{array}{c}13 \\
(8,2 \%)\end{array}$ & 1 & 5 & 3,00 & 4 \\
\hline
\end{tabular}

\begin{tabular}{|c|c|c|c|c|c|c|c|c|c|c|}
\hline \multicolumn{2}{|c|}{$\begin{array}{l}\text { Table 5: Descriptive statistics for Q.7 } \\
\text { "Please rank your Digital creation skills } \\
\text { according to the following areas listed } \\
\text { below": }\end{array}$} & \multicolumn{4}{|c|}{$1=$ Novice, $2=$ Basic, $3=$ Intermediate, $4=$ Advanced, $5=$ Expert } & nediate, 4 & Advan & $d, 5=1$ & pert & \\
\hline & & 1 & 2 & 3 & 4 & 5 & Min. & Max. & Median & Mode \\
\hline 5.1 & $\begin{array}{l}\text { Designing new digital content (valid } \\
\mathrm{N}=163)^{\alpha, \gamma, \mu, \lambda}\end{array}$ & $\begin{array}{c}49 \\
(30,1 \%)\end{array}$ & $\begin{array}{c}38 \\
(23,3 \%)\end{array}$ & $\begin{array}{c}50 \\
(30,7 \%)\end{array}$ & $\begin{array}{c}21 \\
(12,9 \%)\end{array}$ & $\begin{array}{c}5 \\
(3,1 \%)\end{array}$ & 1 & 5 & 2,00 & 3 \\
\hline 5.2 & $\begin{array}{l}\text { Capturing, editing, and producing } \\
\text { digital media (valid } \mathrm{N}=162)^{\sigma, \alpha, v}\end{array}$ & $\begin{array}{c}34 \\
(21 \%)\end{array}$ & $\begin{array}{c}45 \\
(27,8 \%)\end{array}$ & $\begin{array}{c}48 \\
(29,6 \%)\end{array}$ & $\begin{array}{c}27 \\
(16,7 \%)\end{array}$ & $\begin{array}{c}8 \\
(4,9 \%)\end{array}$ & 1 & 5 & 3,00 & 3 \\
\hline 5.3 & $\begin{array}{l}\text { Creating, sharing, and showcasing } \\
\text { digital artefacts, with audience and } \\
\text { purpose in mind (valid } \mathrm{N}=161)^{\sigma, \alpha}\end{array}$ & $\begin{array}{c}36 \\
(22,4 \%)\end{array}$ & $\begin{array}{c}49 \\
(30,4 \%)\end{array}$ & $\begin{array}{c}50 \\
(31,1 \%)\end{array}$ & $\begin{array}{c}21 \\
(13 \%)\end{array}$ & $\begin{array}{c}5 \\
(3,1 \%)\end{array}$ & 1 & 5 & 2,00 & 3 \\
\hline 5.4 & $\begin{array}{l}\text { Coding and designing apps, digital } \\
\text { games, virtual environments, and } \\
\text { interfaces (valid } \mathrm{N}=162)^{\sigma}\end{array}$ & $\begin{array}{c}101 \\
(62,3 \%)\end{array}$ & $\begin{array}{c}32 \\
(19,8 \%)\end{array}$ & $\begin{array}{c}22 \\
(13,6 \%)\end{array}$ & $\begin{array}{c}6 \\
(3,7 \%)\end{array}$ & $\begin{array}{c}1 \\
(0,6 \%)\end{array}$ & 1 & 5 & 1,00 & 1 \\
\hline & ann-Whitney U-test and Kruskal-Wa & I-test $(\sigma$ & 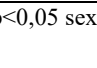 & & & & & & & atus; \\
\hline
\end{tabular}

\begin{tabular}{|c|c|c|c|c|c|c|c|c|c|c|}
\hline \multicolumn{2}{|c|}{$\begin{array}{l}\text { Table 6: Descriptive statistics for Q.8 } \\
\text { "Please rank your Digital research skills in } \\
\text { relation to areas listed below": }\end{array}$} & & $l=N$ & ice, $2=B$ & $c, 3=$ Inte & nediate, & Advan & $d, 5=$ & pert & \\
\hline & & 1 & 2 & 3 & 4 & 5 & Min. & Max. & Median & Mode \\
\hline 6.1 & $\begin{array}{l}\text { Finding digital research data online } \\
\text { (valid } \mathrm{N}=161)^{\sigma, \alpha, \lambda}\end{array}$ & $\begin{array}{c}13 \\
(8,1 \%)\end{array}$ & $\begin{array}{c}31 \\
(19,3 \%)\end{array}$ & $\begin{array}{c}67 \\
(41,6 \%)\end{array}$ & $\begin{array}{c}39 \\
(24,2 \%)\end{array}$ & $\begin{array}{c}11 \\
(6,8 \%)\end{array}$ & 1 & 5 & 3,00 & 3 \\
\hline 6.2 & $\begin{array}{l}\text { Collecting data using digital tools } \\
\text { relevant to your subject area (valid } \\
\mathrm{N}=163)^{\sigma}\end{array}$ & $\begin{array}{c}19 \\
(11,7 \%)\end{array}$ & $\begin{array}{c}40 \\
(24,5 \%)\end{array}$ & $\begin{array}{c}69 \\
(42,3 \%)\end{array}$ & $\begin{array}{c}28 \\
(17,2 \%)\end{array}$ & $\begin{array}{c}7 \\
(4,3 \%)\end{array}$ & 1 & 5 & 3,00 & 3 \\
\hline 6.3 & $\begin{array}{l}\text { Designing and administering data } \\
\text { collection instruments online (valid } \\
\mathrm{N}=162)^{\sigma}\end{array}$ & $\begin{array}{c}35 \\
(21,6 \%)\end{array}$ & $\begin{array}{c}48 \\
(29,6 \%)\end{array}$ & $\begin{array}{c}49 \\
(30,2 \%)\end{array}$ & $\begin{array}{c}26 \\
(16 \%)\end{array}$ & $\begin{array}{c}4 \\
(2,5 \%)\end{array}$ & 1 & 5 & 2,00 & 3 \\
\hline
\end{tabular}




\begin{tabular}{|c|c|c|c|c|c|c|c|c|c|c|}
\hline 6.4 & $\begin{array}{l}\text { Organising and storing digital } \\
\text { research data (valid } \mathrm{N}=163)^{\sigma}\end{array}$ & $\begin{array}{c}18 \\
(11 \%)\end{array}$ & $\begin{array}{c}34 \\
(20,9 \%)\end{array}$ & $\begin{array}{c}44 \\
(27 \%)\end{array}$ & $\begin{array}{c}49 \\
(30,1 \%)\end{array}$ & $\begin{array}{c}18 \\
(11 \%)\end{array}$ & 1 & 5 & 3,00 & 4 \\
\hline 6.5 & $\begin{array}{l}\text { Analysing digital research data using } \\
\text { simple tools (valid } \mathrm{N}=163)^{\sigma, \alpha}\end{array}$ & $\begin{array}{c}25 \\
(15,3 \%)\end{array}$ & $\begin{array}{c}51 \\
(31,3 \%)\end{array}$ & $\begin{array}{c}38 \\
(23,3 \%)\end{array}$ & $\begin{array}{c}35 \\
(21,5 \%)\end{array}$ & $\begin{array}{c}14 \\
(8,6 \%)\end{array}$ & 1 & 5 & 3,00 & 2 \\
\hline 6.6 & $\begin{array}{l}\text { Interpreting digital data for research } \\
\text { purposes (valid } \mathrm{N}=162)^{\alpha, \lambda}\end{array}$ & $\begin{array}{c}31 \\
(19,1 \%)\end{array}$ & $\begin{array}{c}43 \\
(26,5 \%)\end{array}$ & $\begin{array}{c}58 \\
(35,8 \%)\end{array}$ & $\begin{array}{c}21 \\
(13 \%)\end{array}$ & $\begin{array}{c}9 \\
(5,6 \%)\end{array}$ & 1 & 5 & 3,00 & 3 \\
\hline 6.7 & $\begin{array}{l}\text { Understanding how data are used to } \\
\text { construct arguments, make decisions, } \\
\text { and/or solve problems (valid } \\
\mathrm{N}=160)^{\alpha, \gamma, \lambda}\end{array}$ & $\begin{array}{c}19 \\
(11,9 \%)\end{array}$ & $\begin{array}{c}44 \\
(27,5 \%)\end{array}$ & $\begin{array}{c}45 \\
(28,1 \%)\end{array}$ & $\begin{array}{c}41 \\
(25,6 \%)\end{array}$ & $\begin{array}{c}11 \\
(6,9 \%)\end{array}$ & 1 & 5 & 3,00 & 3 \\
\hline 6.8 & $\begin{array}{l}\text { Following ethical, legal, and security } \\
\text { guidelines when using research data } \\
(\text { valid } \mathrm{N}=162)^{\alpha, \gamma, \lambda}\end{array}$ & $\begin{array}{c}23 \\
(14,2 \%)\end{array}$ & $\begin{array}{c}39 \\
(24,1 \%)\end{array}$ & $\begin{array}{c}43 \\
(26,5 \%)\end{array}$ & $\begin{array}{c}44 \\
(27,2 \%)\end{array}$ & $\begin{array}{c}13 \\
(8 \%)\end{array}$ & 1 & 5 & 3,00 & 4 \\
\hline $\begin{array}{l}\text { No } \\
\lambda: p\end{array}$ & $\begin{array}{l}\text { Tann-Whitney U-test and Kruskal-W } \\
5 \text { current level of study). }\end{array}$ & 8 & $05 \mathrm{~s}$ & $\angle 00$ & & & & & & \\
\hline
\end{tabular}

\begin{tabular}{|c|c|c|c|c|c|c|c|c|c|c|}
\hline \multicolumn{2}{|c|}{$\begin{array}{l}\text { Table 7: Descriptive statistics for Q.9 } \\
\text { "Please rank your Digital communication } \\
\text { skills in relation to areas listed below": }\end{array}$} & \multicolumn{9}{|c|}{$1=$ Novice, $2=$ Basic, $3=$ Intermediate, $4=$ Advanced, $5=$ Expert } \\
\hline & & 1 & 2 & 3 & 4 & 5 & Min. & Max. & Median & Mode \\
\hline 7.1 & $\begin{array}{l}\text { Participating in a range of digital } \\
\text { networks related to your interests, } \\
\text { work, and/or academic subject (valid } \\
\mathrm{N}=162)^{\alpha, \gamma}\end{array}$ & $\begin{array}{c}22 \\
(13,6 \%)\end{array}$ & $\begin{array}{c}41 \\
(25,3 \%)\end{array}$ & $\begin{array}{c}48 \\
(29,6 \%)\end{array}$ & $\begin{array}{c}43 \\
(26,5 \%)\end{array}$ & $\begin{array}{c}8 \\
(4,9 \%)\end{array}$ & 1 & 5 & 3,00 & 3 \\
\hline 7.2 & $\begin{array}{l}\text { Understanding acceptable ways of } \\
\text { interacting in particular digital } \\
\text { contexts (valid } \mathrm{N}=163)^{\alpha, \gamma, \mu, \lambda}\end{array}$ & $\begin{array}{c}15 \\
(9,2 \%)\end{array}$ & $\begin{array}{c}23 \\
(14,1 \%)\end{array}$ & $\begin{array}{c}61 \\
(37,4 \%)\end{array}$ & $\begin{array}{c}48 \\
(29,4 \%)\end{array}$ & $\begin{array}{c}16 \\
(9,8 \%)\end{array}$ & 1 & 5 & 3,00 & 3 \\
\hline 7.3 & $\begin{array}{l}\text { Communicating respectfully and } \\
\text { inclusively, recognising that digital } \\
\text { media can be used to intimidate, } \\
\text { shame, and harass other people } \\
\text { (valid } \mathrm{N}=162 \text { ) }\end{array}$ & $\begin{array}{c}4 \\
(2,5 \%)\end{array}$ & $\begin{array}{c}13 \\
(8 \%)\end{array}$ & $\begin{array}{c}37 \\
(22,8 \%)\end{array}$ & $\begin{array}{c}68 \\
(42 \%)\end{array}$ & $\begin{array}{c}40 \\
(24,7 \%)\end{array}$ & 1 & 5 & 4,00 & 4 \\
\hline 7.4 & $\begin{array}{l}\text { Recognising false or damaging } \\
\text { digital communications (valid } \\
\mathrm{N}=161 \text { ) }\end{array}$ & $\begin{array}{c}9 \\
(5,6 \%)\end{array}$ & $\begin{array}{c}16 \\
(9,9 \%)\end{array}$ & $\begin{array}{c}53 \\
(32,9 \%)\end{array}$ & $\begin{array}{c}50 \\
(31,1 \%)\end{array}$ & $\begin{array}{c}33 \\
(20,5 \%)\end{array}$ & 1 & 5 & 4,00 & 3 \\
\hline 7.5 & $\begin{array}{l}\text { Sharing any specialist ideas (valid } \\
\mathrm{N}=157)^{\alpha}\end{array}$ & $\begin{array}{c}16 \\
(10,2 \%)\end{array}$ & $\begin{array}{c}39 \\
(24,8 \%)\end{array}$ & $\begin{array}{c}72 \\
(45,9 \%)\end{array}$ & $\begin{array}{c}22 \\
(14 \%)\end{array}$ & $\begin{array}{c}8 \\
(5,1 \%)\end{array}$ & 1 & 5 & 3,00 & 3 \\
\hline 7.6 & $\begin{array}{l}\text { Designing digital communications } \\
\text { for different purposes (valid } \\
\mathrm{N}=159)^{\sigma, \alpha}\end{array}$ & $\begin{array}{c}25 \\
(15,7 \%)\end{array}$ & $\begin{array}{c}40 \\
(25,2 \%)\end{array}$ & $\begin{array}{c}58 \\
(36,5 \%)\end{array}$ & $\begin{array}{c}30 \\
(18,9 \%)\end{array}$ & $\begin{array}{c}6 \\
(3,8 \%)\end{array}$ & 1 & 5 & 3,00 & 3 \\
\hline & $\begin{array}{l}\text { Uann-Whitney U-test and Kruskal-W } \\
05 \text { current level of study). }\end{array}$ & H-test & $<<0,05 \mathrm{se}$ & $: \mathrm{p}<0,0$ & $\gamma: \mathrm{p}$ & count & es1 & $\mu:$ & $5 \mathrm{mar}$ & tatus; \\
\hline
\end{tabular}

\begin{tabular}{|c|c|}
\hline $\begin{array}{l}\text { Table 8: Descriptive statistics for Q.10 } \\
\text { "Please rank your Digital innovation in } \\
\text { relation to areas listed below": }\end{array}$ & $\begin{array}{c}\text { Competences Level Scale } \\
1=\text { Novice, } 2=\text { Basic, } 3=\text { Intermediate, } 4=\text { Advanced, } 5=\text { Expert }\end{array}$ \\
\hline
\end{tabular}




\begin{tabular}{|c|c|c|c|c|c|c|c|c|c|c|}
\hline & & 1 & 2 & 3 & 4 & 5 & Min. & Max. & Median & Mode \\
\hline 8.1 & $\begin{array}{l}\text { Developing new ideas and projects } \\
\text { using digital technologies (valid } \\
\mathrm{N}=159)^{\alpha}\end{array}$ & $\begin{array}{c}32 \\
(20,1 \%)\end{array}$ & $\begin{array}{c}45 \\
(28,3 \%)\end{array}$ & $\begin{array}{c}59 \\
(37,1 \%)\end{array}$ & $\begin{array}{c}14 \\
(8,8 \%)\end{array}$ & $\begin{array}{c}9 \\
(5,7 \%)\end{array}$ & 1 & 5 & 3,00 & 3 \\
\hline 8.2 & $\begin{array}{l}\text { Promoting new digital tools and } \\
\text { opportunities to others (valid } \mathrm{N}=158 \text { ) }\end{array}$ & $\begin{array}{c}33 \\
(20,9 \%)\end{array}$ & $\begin{array}{c}44 \\
(27,8 \%)\end{array}$ & $\begin{array}{c}55 \\
(34,8 \%)\end{array}$ & $\begin{array}{c}18 \\
(11,4 \%)\end{array}$ & $\begin{array}{c}8 \\
(5,1 \%)\end{array}$ & 1 & 5 & 3,00 & 3 \\
\hline & ann-Whitney U-test and Kruskal-Wa & H-test & $<0,05 \mathrm{ag}$ & & & & & & & \\
\hline
\end{tabular}

\begin{tabular}{|c|c|c|c|c|c|c|c|c|c|c|}
\hline \multicolumn{2}{|c|}{$\begin{array}{l}\text { Table 9: Descriptive statistics for Q.11 } \\
\text { "Please rank your Digital learning and } \\
\text { development in relation to areas listed } \\
\text { below": }\end{array}$} & \multicolumn{9}{|c|}{$\begin{array}{ll}\text { Competences Level Scale } \\
\end{array}$} \\
\hline 9.1 & $\begin{array}{l}\text { Participating in digital learning } \\
\text { opportunities and resources (valid } \\
\mathrm{N}=162)^{\alpha, \gamma, \mu, \lambda}\end{array}$ & $\begin{array}{c}20 \\
(12,3 \%)\end{array}$ & $\begin{array}{c}38 \\
(23,5 \%)\end{array}$ & $\begin{array}{c}56 \\
(34,6 \%)\end{array}$ & $\begin{array}{c}35 \\
(21,6 \%)\end{array}$ & $\begin{array}{c}13 \\
(8 \%)\end{array}$ & 1 & 5 & 3,00 & 3 \\
\hline 9.2 & $\begin{array}{l}\text { Adopting new ways of learning } \\
\text { online (valid } \mathrm{N}=160)^{\alpha, \gamma, \mu, \lambda}\end{array}$ & $\begin{array}{c}21 \\
(13,1 \%)\end{array}$ & $\begin{array}{c}30 \\
(18,8 \%)\end{array}$ & $\begin{array}{c}46 \\
(28,7 \%)\end{array}$ & $\begin{array}{c}51 \\
(31,9 \%)\end{array}$ & $\begin{array}{c}12 \\
(7,5 \%)\end{array}$ & 1 & 5 & 3,00 & 4 \\
\hline 9.3 & $\begin{array}{l}\text { Working collaboratively and } \\
\text { supportively with other learners, } \\
\text { using digital technologies where } \\
\text { appropriate (valid } \mathrm{N}=163)^{\alpha}\end{array}$ & $\begin{array}{c}22 \\
(13,5 \%)\end{array}$ & $\begin{array}{c}35 \\
(21,5 \%)\end{array}$ & $\begin{array}{c}49 \\
(30,1 \%)\end{array}$ & $\begin{array}{c}47 \\
(28,8 \%)\end{array}$ & $\begin{array}{c}10 \\
(6,1 \%)\end{array}$ & 1 & 5 & 3,00 & 3 \\
\hline 9.4 & $\begin{array}{l}\text { Using digital tools to take notes, } \\
\text { annotate, collate and curate learning } \\
\text { materials, review, and revise learning } \\
\text { (valid } \mathrm{N}=162)^{\alpha, \gamma}\end{array}$ & $\begin{array}{c}24 \\
(14,8 \%)\end{array}$ & $\begin{array}{c}35 \\
(21,6 \%)\end{array}$ & $\begin{array}{c}62 \\
(38,3 \%)\end{array}$ & $\begin{array}{c}36 \\
(22,2 \%)\end{array}$ & $\begin{array}{c}5 \\
(3,1 \%)\end{array}$ & 1 & 5 & 3,00 & 3 \\
\hline 9.5 & $\begin{array}{l}\text { Using digital tools to record learning } \\
\text { events/outcomes and use them for } \\
\text { self-analysis, reflection, and } \\
\text { showcasing of achievement (valid } \\
\mathrm{N}=161)^{\alpha}\end{array}$ & $\begin{array}{c}39 \\
(24,2 \%)\end{array}$ & $\begin{array}{c}46 \\
(28,6 \%)\end{array}$ & $\begin{array}{c}49 \\
(30,4 \%)\end{array}$ & $\begin{array}{c}22 \\
(13,7 \%)\end{array}$ & $\begin{array}{c}5 \\
(3,1 \%)\end{array}$ & 1 & 5 & 2,00 & 3 \\
\hline 9.6 & $\begin{array}{l}\text { Receiving and responding to digital } \\
\text { feedback about your academic work } \\
(\text { valid } N=161)^{\alpha, \gamma, \mu, \lambda}\end{array}$ & $\begin{array}{c}29 \\
(18 \%)\end{array}$ & $\begin{array}{c}39 \\
(24,2 \%)\end{array}$ & $\begin{array}{c}49 \\
(30,4 \%)\end{array}$ & $\begin{array}{c}38 \\
(23,6 \%)\end{array}$ & $\begin{array}{c}6 \\
(3,7 \%)\end{array}$ & 1 & 5 & 3,00 & 3 \\
\hline 9.7 & $\begin{array}{l}\text { Managing your engagement and } \\
\text { participation in digital learning } \\
\text { environments (valid } \mathrm{N}=159)^{\alpha, \gamma, \mu, \lambda}\end{array}$ & $\begin{array}{c}24 \\
(15,1 \%)\end{array}$ & $\begin{array}{c}38 \\
(23,9 \%)\end{array}$ & $\begin{array}{c}57 \\
(35,8 \%)\end{array}$ & $\begin{array}{c}35 \\
(22 \%)\end{array}$ & $\begin{array}{c}5 \\
(3,1 \%)\end{array}$ & 1 & 5 & 3,00 & 3 \\
\hline 9.8 & $\begin{array}{l}\text { Sharing your digital know-how and } \\
\text { digitally guide other learners (valid } \\
\mathrm{N}=160)^{\alpha}\end{array}$ & $\begin{array}{c}34 \\
(21,3 \%)\end{array}$ & $\begin{array}{c}32 \\
(20 \%)\end{array}$ & $\begin{array}{c}55 \\
(34,4 \%)\end{array}$ & $\begin{array}{c}28 \\
(17,5 \%)\end{array}$ & $\begin{array}{c}11 \\
(6,9 \%)\end{array}$ & 1 & 5 & 3,00 & 3 \\
\hline & $\begin{array}{l}\text { Tann-Whitney U-test and Kruskal-Wa } \\
\text { level of study). }\end{array}$ & -test $(0$ & 05 as & $\overline{<<0,05}$ & intry of 1 & ence; 1 & $<0,05$ & arital & $; \lambda: p<0$ & \\
\hline
\end{tabular}

\begin{tabular}{|c|c|c|c|c|c|c|c|c|c|}
\hline \multirow{2}{*}{$\begin{array}{l}\text { Table 10: Descriptive statistics for Q.12 "Which } \\
\text { level best describes your digital abilities to } \\
\text { complete your academic work?": }\end{array}$} & \multicolumn{9}{|c|}{ Competences Level Scale } \\
\hline & 1 & 2 & 3 & 4 & 5 & Min. & Max. & Median & Mode \\
\hline
\end{tabular}




\begin{tabular}{|c|l|c|c|c|c|c|c|c|c|}
\hline 10.1 & $\begin{array}{l}\text { Level of digital abilities (valid } \\
\mathrm{N}=161)^{\alpha, \gamma, \lambda}\end{array}$ & 16 & 29 & 68 & 40 & 8 & 1 & 5 & 3,00 \\
$(9,9 \%)$ & $(18 \%)$ & $(42,2 \%)$ & $(24,8 \%)$ & $(5 \%)$ & 3 & \\
\hline
\end{tabular}

\begin{tabular}{|c|c|c|c|c|c|c|c|c|c|c|}
\hline \multirow{2}{*}{\multicolumn{2}{|c|}{$\begin{array}{l}\text { Table 11: Descriptive statistics for Q.13 } \\
\text { "Please rank your Digital identity } \\
\text { management in relation to the areas listed } \\
\text { below": }\end{array}$}} & \multicolumn{9}{|c|}{ Competences Level Scale } \\
\hline & & 1 & 2 & 3 & 4 & 5 & Min. & Max. & Median & Mode \\
\hline 11.1 & $\begin{array}{l}\text { Managing your online profiles on } \\
\text { different digital media in a way that } \\
\text { is suitable for personal, } \\
\text { professional, and academic } \\
\text { purposes (valid } \mathrm{N}=163)^{\lambda}\end{array}$ & $\begin{array}{c}7 \\
(4,3 \%)\end{array}$ & $\begin{array}{c}18 \\
(11 \%)\end{array}$ & $\begin{array}{c}66 \\
(40,5 \%)\end{array}$ & $\begin{array}{c}50 \\
(30,7 \%)\end{array}$ & $\begin{array}{c}22 \\
(13,5 \%)\end{array}$ & 1 & 5 & 3,00 & 3 \\
\hline 11.2 & $\begin{array}{l}\text { Understanding how your online } \\
\text { personal data are collected and } \\
\text { used in different systems and use } \\
\text { privacy settings appropriately } \\
(\text { valid } N=161)^{\mu}\end{array}$ & $\begin{array}{c}7 \\
(4,3 \%)\end{array}$ & $\begin{array}{c}34 \\
(21,1 \%)\end{array}$ & $\begin{array}{c}59 \\
(36,6 \%)\end{array}$ & $\begin{array}{c}52 \\
(32,3 \%)\end{array}$ & $\begin{array}{c}9 \\
(5,6 \%)\end{array}$ & 1 & 5 & 3,00 & 3 \\
\hline 11.3 & $\begin{array}{l}\text { Being aware of the potential } \\
\text { positive or negative impact of what } \\
\text { you communicate online on your } \\
\text { digital reputation (valid } \mathrm{N}=163)^{\gamma, \mu, \lambda}\end{array}$ & $\begin{array}{c}11 \\
(6,7 \%)\end{array}$ & $\begin{array}{c}16 \\
(9,8 \%)\end{array}$ & $\begin{array}{c}42 \\
(25,8 \%)\end{array}$ & $\begin{array}{c}76 \\
(46,6 \%)\end{array}$ & $\begin{array}{c}18 \\
(11 \%)\end{array}$ & 1 & 5 & 4,00 & 4 \\
\hline 11.4 & $\begin{array}{l}\text { Making sure outcomes of learning } \\
\text { and other achievements are } \\
\text { accessible in digital forms (valid } \\
\mathrm{N}=160)^{\alpha}\end{array}$ & $\begin{array}{c}19 \\
(11,9 \%)\end{array}$ & $\begin{array}{c}36 \\
(22,5 \%)\end{array}$ & $\begin{array}{c}67 \\
(41,9 \%)\end{array}$ & $\begin{array}{c}30 \\
(18,8 \%)\end{array}$ & $\begin{array}{c}8 \\
(5 \%)\end{array}$ & 1 & 5 & 3,00 & 3 \\
\hline 11.5 & $\begin{array}{l}\text { Analysing your digital impact, } \\
\text { footprint, and reputation using } \\
\text { analytics or other digital tools } \\
(\text { valid } \mathrm{N}=160)^{\sigma, \alpha}\end{array}$ & $\begin{array}{c}41 \\
(25,6 \%)\end{array}$ & $\begin{array}{c}51 \\
(31,9 \%)\end{array}$ & $\begin{array}{c}46 \\
(28,7 \%)\end{array}$ & $\begin{array}{c}20 \\
(12,5 \%)\end{array}$ & $\begin{array}{c}2 \\
(1,3 \%)\end{array}$ & 1 & 5 & 2,00 & 2 \\
\hline 11.6 & $\begin{array}{l}\text { Linking and curating personal } \\
\text { identities (valid } \mathrm{N}=160)^{\sigma, \alpha}\end{array}$ & $\begin{array}{c}43 \\
(26,9 \%)\end{array}$ & $\begin{array}{c}33 \\
(20,6 \%)\end{array}$ & $\begin{array}{c}44 \\
(27,5 \%)\end{array}$ & $\begin{array}{c}31 \\
(19,4 \%)\end{array}$ & $\begin{array}{c}9 \\
(5,6 \%)\end{array}$ & 1 & 5 & 3,00 & 3 \\
\hline \multicolumn{11}{|c|}{$\begin{array}{l}\text { Note: Mann-Whitney U-test and Kruskal-Wallis H-test ( } \sigma: p<0,05 \text { sex; } \alpha \text { : } p<0,05 \text { age; } \gamma: p<0,05 \text { country of residence; } \mu \text { : } p<0,05 \text { marital status; } \\
\lambda: p<0,05 \text { current level of study). }\end{array}$} \\
\hline
\end{tabular}

\begin{tabular}{|c|c|c|c|c|c|c|c|c|c|c|}
\hline \multicolumn{2}{|c|}{$\begin{array}{l}\text { Table 12: Descriptive statistics for Q.14 } \\
\text { "Please rank your Digital wellbeing in } \\
\text { relation to the areas listed below": }\end{array}$} & \multicolumn{9}{|c|}{ Competences Level Scale } \\
\hline & & 1 & 2 & 3 & 4 & 5 & Min. & Max. & Median & Mode \\
\hline 12.1 & $\begin{array}{l}\text { Feeling comfortable, in control, } \\
\text { and safe when using digital } \\
\text { technologies (valid } \mathrm{N}=163)^{\sigma}\end{array}$ & $\begin{array}{c}5 \\
(3,1 \%)\end{array}$ & $\begin{array}{c}32 \\
(19,6 \%)\end{array}$ & $\begin{array}{c}50 \\
(30,7 \%)\end{array}$ & $\begin{array}{c}54 \\
(33,1 \%)\end{array}$ & $\begin{array}{c}22 \\
(13,5 \%)\end{array}$ & 1 & 5 & 3,00 & 4 \\
\hline 12.2 & $\begin{array}{l}\text { Recognising that digital } \\
\text { information and media can cause } \\
\text { distraction, overload, and stress, } \\
\text { and disconnecting when necessary } \\
\text { (valid } \mathrm{N}=163 \text { ) }\end{array}$ & $\begin{array}{c}7 \\
(4,3 \%)\end{array}$ & $\begin{array}{c}9 \\
(5,5 \%)\end{array}$ & $\begin{array}{c}29 \\
(17,8 \%)\end{array}$ & $\begin{array}{c}80 \\
(49,1 \%)\end{array}$ & $\begin{array}{c}38 \\
(23,3 \%)\end{array}$ & 1 & 5 & 4,00 & 4 \\
\hline 12.3 & $\begin{array}{l}\text { Considering the rights and wrongs } \\
\text { and the possible consequences of }\end{array}$ & $\begin{array}{c}5 \\
(3,1 \%)\end{array}$ & $\begin{array}{c}6 \\
(3,7 \%)\end{array}$ & $\begin{array}{c}47 \\
(28,8 \%)\end{array}$ & $\begin{array}{c}67 \\
(41,1 \%)\end{array}$ & $\begin{array}{c}38 \\
(23,3 \%)\end{array}$ & 1 & 5 & 4,00 & 4 \\
\hline
\end{tabular}




\begin{tabular}{|c|c|c|c|c|c|c|c|c|c|c|}
\hline & $\begin{array}{l}\text { your online behaviour (valid } \\
\mathrm{N}=163 \text { ) }\end{array}$ & & & & & & & & & \\
\hline 12.4 & $\begin{array}{l}\text { Acting positively against } \\
\text { cyberbullying and other damaging } \\
\text { online behaviours (valid } \mathrm{N}=161 \text { ) }\end{array}$ & $\begin{array}{c}8 \\
(5 \%)\end{array}$ & $16(9,9 \%)$ & $\begin{array}{c}43 \\
(26,7 \%)\end{array}$ & $\begin{array}{c}74 \\
(46 \%)\end{array}$ & $\begin{array}{c}20 \\
(12,4 \%)\end{array}$ & 1 & 5 & 4,00 & 4 \\
\hline 12.5 & $\begin{array}{l}\text { Using digital media to access } \\
\text { services, monitor health conditions, } \\
\text { and participate in the community } \\
\text { (valid } \mathrm{N}=163 \text { ) }\end{array}$ & $\begin{array}{c}16 \\
(9,8 \%)\end{array}$ & $\begin{array}{c}17 \\
(10,4 \%)\end{array}$ & $\begin{array}{c}64 \\
(39,3 \%)\end{array}$ & $\begin{array}{c}52 \\
(31,9 \%)\end{array}$ & $\begin{array}{c}14 \\
(8,6 \%)\end{array}$ & 1 & 5 & 3,00 & 3 \\
\hline 12.6 & $\begin{array}{l}\text { Managing online and real-world } \\
\text { interactions in ways that support } \\
\text { healthy relationships (valid } \\
\mathrm{N}=163)^{\lambda, v}\end{array}$ & $\begin{array}{c}9 \\
(5,5 \%)\end{array}$ & $\begin{array}{c}16 \\
(9,8 \%)\end{array}$ & $\begin{array}{c}59 \\
(36,2 \%)\end{array}$ & $\begin{array}{c}54 \\
(33,1 \%)\end{array}$ & $\begin{array}{c}25 \\
(15,3 \%)\end{array}$ & 1 & 5 & 3,00 & 3 \\
\hline
\end{tabular}

\section{Appendix II -}

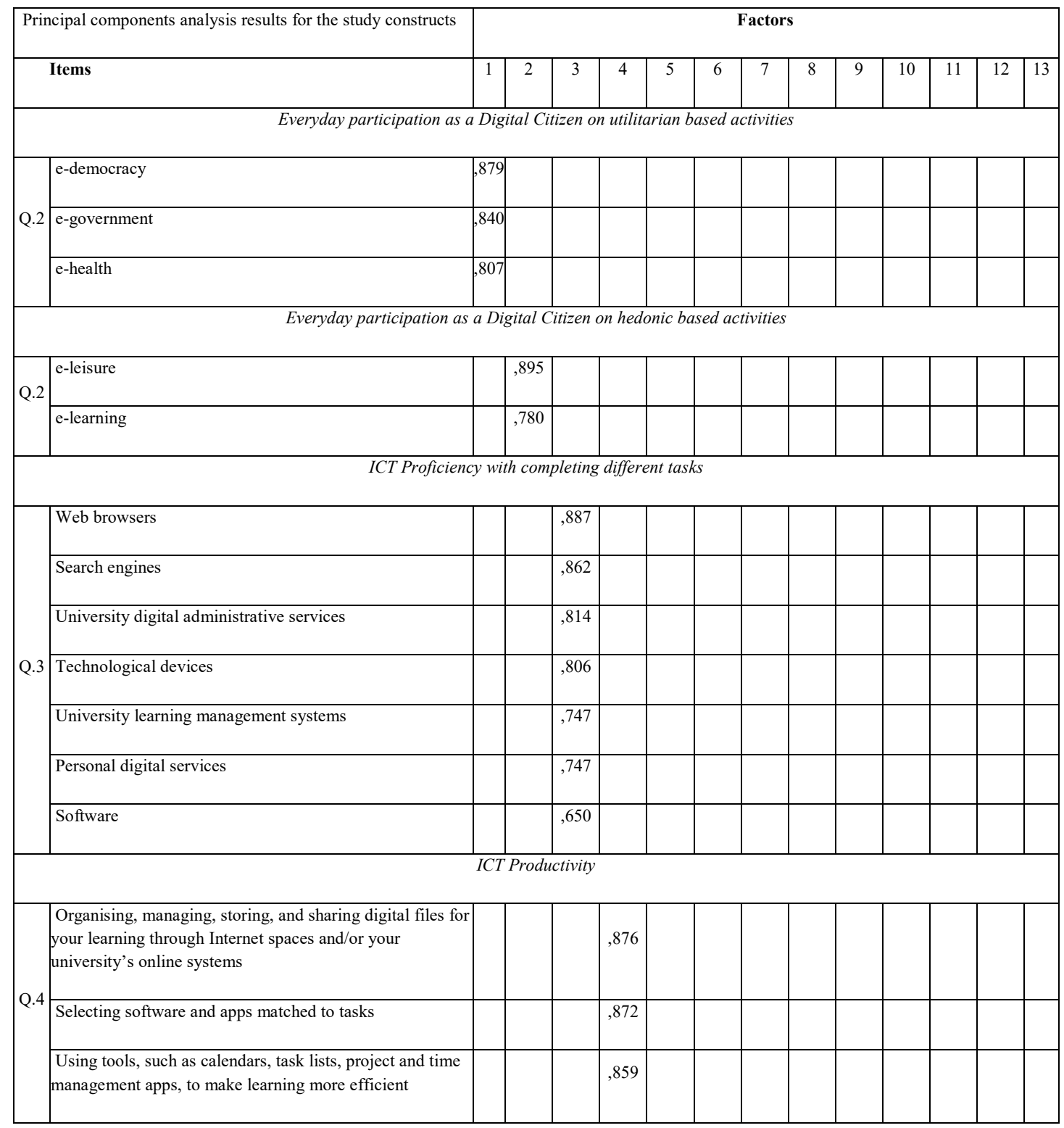




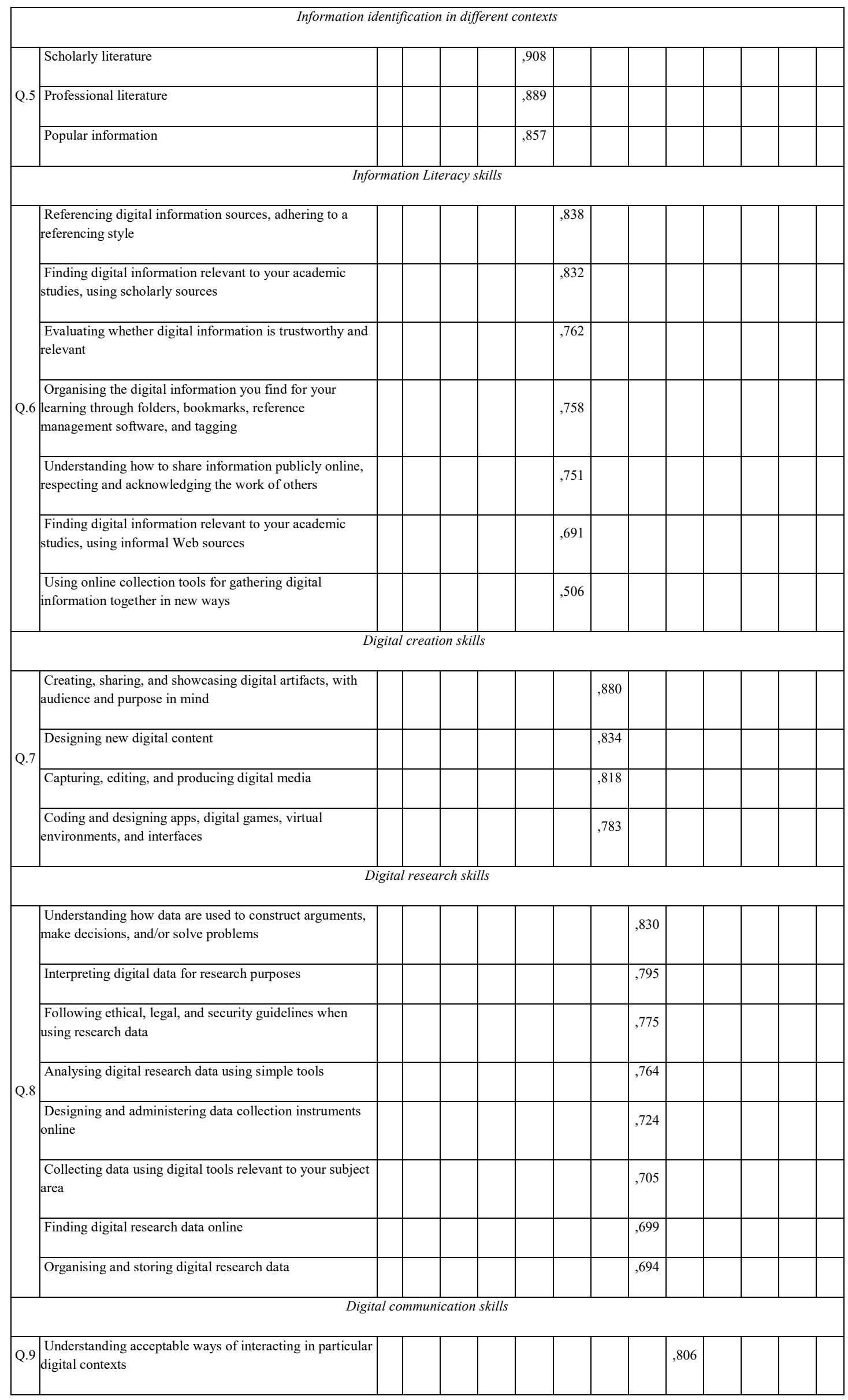




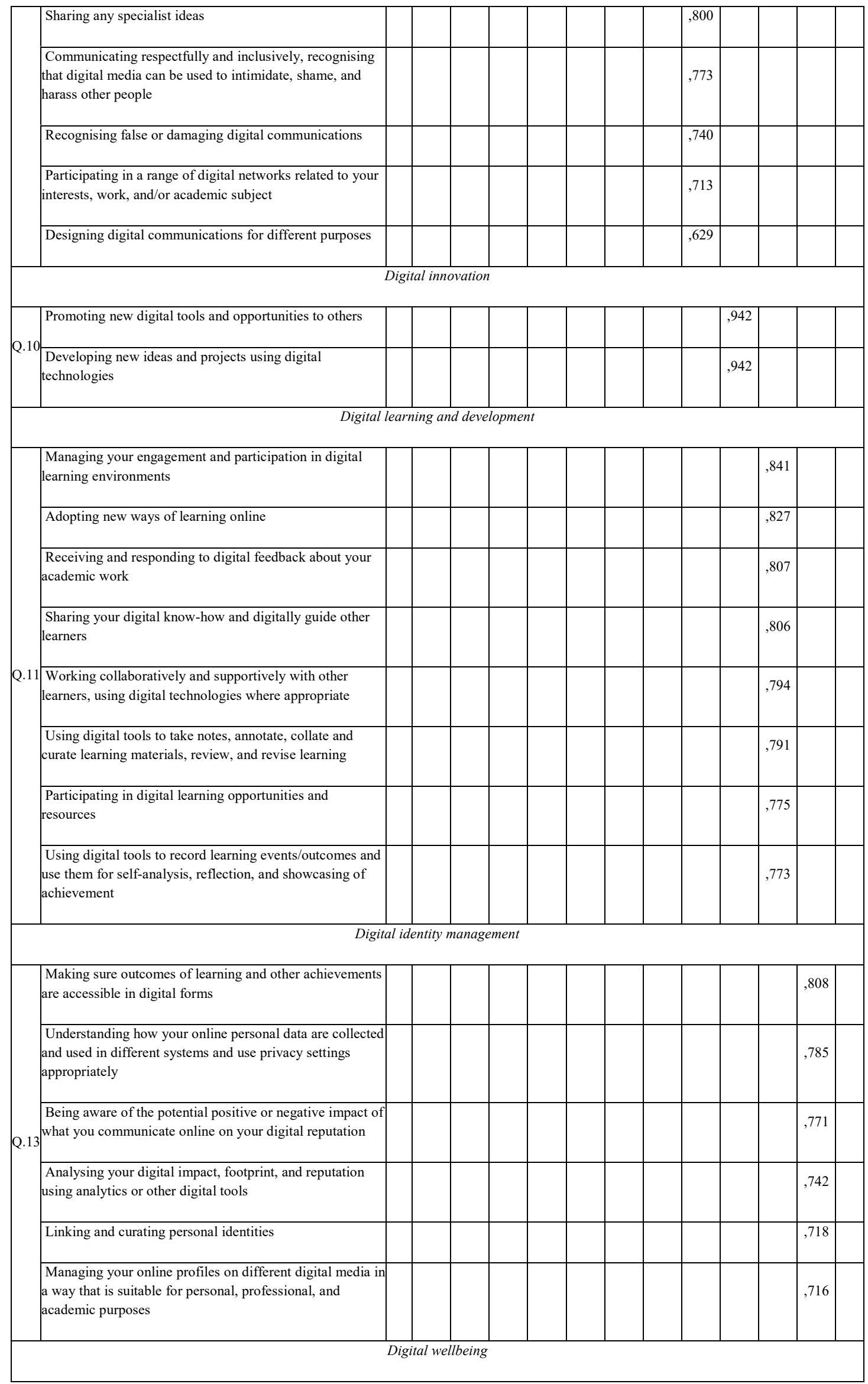




\begin{tabular}{|c|c|c|c|c|c|c|c|c|c|c|c|c|c|c|}
\hline & $\begin{array}{l}\text { Managing online and real-world interactions in ways that } \\
\text { support healthy relationships }\end{array}$ & & & & & & & & & & & & & 825 \\
\hline & $\begin{array}{l}\text { Acting positively against cyberbullying and other } \\
\text { damaging online behaviours }\end{array}$ & & & & & & & & & & & & & 818 \\
\hline & $\begin{array}{l}\text { Considering the rights and wrongs and the possible } \\
\text { consequences of your online behaviour }\end{array}$ & & & & & & & & & & & & &, 788 \\
\hline Q.14 $\begin{array}{l}\mathrm{F} \\
\mathrm{d} \\
\mathrm{n}\end{array}$ & $\begin{array}{l}\text { Recognising that digital information and media can cause } \\
\text { distraction, overload, and stress, and disconnecting when } \\
\text { necessary }\end{array}$ & & & & & & & & & & & & &, 762 \\
\hline & $\begin{array}{l}\text { Using digital media to access services, monitor health } \\
\text { conditions, and participate in the community }\end{array}$ & & & & & & & & & & & & &, 719 \\
\hline & $\begin{array}{l}\text { Feeling comfortable, in control, and safe when using } \\
\text { digital technologies }\end{array}$ & & & & & & & & & & & & &, 686 \\
\hline & & actors & Inter & nal Re & liabilit & & & & & & & & & \\
\hline & Cronbach's Alpha & 820 & 652 & ,898 & ,838 & 861 & ,859 & ,848 & ,888 & ,839 & ,874 & ,921 & ,851 & $\overline{860}$ \\
\hline & Mean & 2,29 & 3,41 & 3,72 & 3,06 & 2,94 & 2,95 & 2,24 & 2,81 & 3,12 & 2,51 & 2,77 & 2,97 & 2,94 \\
\hline & Std. Deviation & 1,02 & ,938 & ,749 & ,862 & ,978 & ,805 & 880 & 829 & ,798 & 1,02 & ,896 & 1,01 & 797 \\
\hline
\end{tabular}

